\title{
RalA and RalB Function as the Critical GTP Sensors for GTP-Dependent Exocytosis
}

\author{
Gang Li, ${ }^{1,2}$ Liping Han, ${ }^{1,2}$ Ting-Chieh Chou, ${ }^{1,2}$ Yoshihito Fujita, ${ }^{1}$ Lakshmanan Arunachalam, ${ }^{1,2}$ Ainan Xu, ${ }^{1}$ Aaron Wong, \\ Soon-Kwang Chiew, ${ }^{1}$ Qi Wan, ${ }^{1,2}$ Li Wang, ${ }^{1}$ and Shuzo Sugita ${ }^{1,2}$ \\ ${ }^{1}$ Division of Cellular and Molecular Biology, Toronto Western Research Institute, University Health Network, Toronto, Ontario, Canada M5T 2S8, and \\ ${ }^{2}$ Department of Physiology, University of Toronto, Toronto, Ontario, Canada M5S 1A8
}

\begin{abstract}
Although it has been established that the activation of GTPases by non-hydrolyzable GTP stimulates neurotransmitter release from many different secretory cell types, the underlying mechanisms remain unclear. In the present study we aimed to elucidate the functional role(s) for endogenous Ras-like protein A (RalA) and RalB GTPases in GTP-dependent exocytosis. For this purpose stable neuroendocrine pheochromocytoma 12 (PC12) cell lines were generated in which the expressions of both RalA and RalB were strongly downregulated. In these double knock-down cells GTP-dependent exocytosis was reduced severely and was restored after the expression of RalA or RalB was reintroduced by transfection. In contrast, $\mathrm{Ca}^{2+}$-dependent exocytosis and the docking of dense core vesicles analyzed by electron microscopy remained unchanged in the double knock-down cells. Furthermore, the transfected RalA and RalB appeared to be localized primarily on the dense core vesicles in undifferentiated and nerve growth factor-differentiated PC12 cells. Our results indicate that endogenous RalA and RalB function specifically as GTP sensors for the GTP-dependent exocytosis of dense core vesicles, but they are not required for the general secretory pathways, including tethering of vesicles to the plasma membrane and $\mathrm{Ca}^{2+}$-dependent exocytosis.
\end{abstract}

Key words: exocytosis; Ral; exocyst; RNA interference; PC12 cells; dense core vesicles

\section{Introduction}

Many secretory cells trigger exocytosis by GTP-dependent pathways, because sustained activation of one or more GTP-binding proteins by non-hydrolyzable GTP analogs has been shown to stimulate exocytosis without elevating intracellular $\mathrm{Ca}^{2+}$ (Tse and Tse, 2000). Using secretion assays with permeabilized pheochromocytoma 12 (PC12) cells, we recently have demonstrated that soluble recombinant Ras-like protein A (RalA) strongly inhibits GTP-dependent exocytosis by functioning as a dominant negative (Wang et al., 2004). Although this result suggests a potential involvement of RalA in GTP-dependent exocytosis, the critical role for endogenous RalA in this process remains to be understood fully.

It recently was discovered that mammalian exocyst proteins function as effectors for RalA and RalB GTPases (Brymora et al., 2001; Moskalenko et al., 2002; Sugihara et al., 2002). The exocyst protein complex originally was identified in yeast (TerBush and Novick, 1995; TerBush et al., 1996) and functions as an effector

\footnotetext{
Received June 16, 2006; revised Nov. 6, 2006; accepted Nov. 27, 2006.

This research was supported by the Canada Research Chair program, Natural Sciences and Engineering Research Council of Canada (456042), and the Canadian Institute of Health Research (MOP-57825). We thank Drs. R. Agami, A. Miyawaki, R. Jahn, J. Jununtra, R. Bremner, and P. Monnier for providing reagents for this study. We also thank Mr. Steven Doyle for his excellent technical help in electron microscopy, conducted in the Microscopy Imaging Laboratory at the University of Toronto. Finally, we thank Dr. Tony Collins for his excellent help in confocal microscopy conducted in the Wright Cell Imaging Facility at Toronto Western Research Institute.

Correspondence should be addressed to Dr. Shuzo Sugita, Toronto Western Research Institute, MC11-432, University Health Network, 399 Bathurst Street, Toronto, Ontario, Canada M5T 2S8. E-mail: ssugita@uhnres. utoronto.ca.

DOI:10.1523/JNEUROSCI.2537-06.2007

Copyright $\odot 2007$ Society for Neuroscience $\quad$ 0270-6474/07/270190-13\$15.00/0
}

for Sec4p GTPase (Guo et al., 1999). Yeast exocyst proteins and Sec4p are essential for delivering secretory vesicles to the tip of budding sites. Similar to the yeast exocyst, the mammalian exocyst is an octameric protein complex of Sec3, Sec5, Sec6, Sec8, Sec10, Sec15, exocyst complex component 70 (Exo70), and Exo84 (Hsu et al., 1996; Kee et al., 1997). Among these proteins, Sec5 and Exo84 physically interact with RalA and RalB in a GTPdependent manner (Fukai et al., 2003; Moskalenko et al., 2003; Jin et al., 2005). Drawing from observations in yeast, researchers have speculated that exocyst proteins in mammalian cells play a role for tethering secretory vesicles to the plasma membrane. Indeed, the overexpression of truncated, dominant-negative Sec 8 or Sec10 mutants decreased the number of vesicles docked at the plasma membrane in insulinoma cells (Tsuboi et al., 2005). We previously showed that a fragment of Sec5 that binds RalA dominant-negatively inhibits GTP-dependent exocytosis (Wang et al., 2004), which suggests that, in addition to RalA, the exocyst proteins are critical for this process.

Recent studies using knock-down approaches suggested that RalA/RalB or RalA or RalB is involved in neurite outgrowth in cortical neurons (Lalli and Hall, 2005) and cell migration (Rosse et al., 2006). The role for RalA/RalB in $\mathrm{Ca}^{2+}$-dependent exocytosis also was analyzed via transient manipulation of RalA/RalB expression levels in PC12 cells (Moskalenko et al., 2003; Vitale et al., 2005). However, these two studies led to contradictory conclusions. Furthermore, in permeabilized PC12 secretion assays we did not find evidence that RalA is involved in $\mathrm{Ca}^{2+}$ dependent exocytosis (Wang et al., 2004).

To address the role for endogenous RalA and RalB in GTPand $\mathrm{Ca}^{2+}$-dependent exocytosis, we have generated stable PC12 
cells in which both RalA and RalB are strongly downregulated. PC12 cells exhibit robust regulated exocytosis of catecholamines in both $\mathrm{Ca}^{2+}$ - and GTP-dependent manners. In addition, the differentiation of PC12 cells can be induced by nerve growth factor (NGF) (Greene and Tischler, 1976), which allows us to study the role for Ral proteins in neurite outgrowth. Via detailed phenotypic analysis of the double knock-down PC12 cells and rescue experiments, we demonstrate the critical function of Ral proteins in GTP-dependent exocytosis.

\section{Materials and Methods}

General materials. Parental pSuper plasmid for knock-down constructs (Brummelkamp et al., 2002) was a kind gift from Dr. Reuven Agami (Center for Biomedical Genetics, Utrecht, The Netherlands). Plasmid pVenus-N1-neuropeptide-Y (NPY) (Nagai et al., 2002) was a kind gift from Dr. Atsushi Miyawaki (The Institute of Physical and Chemical Research, Wako, Saitama, Japan). Plasmid pBabe-puro (Brummelkamp et al., 2002) and the plasmid containing human placental alkaline phosphatase cDNA were obtained from Drs. Rod Bremner and Philippe Monnier (University Health Network, Toronto, Ontario, Canada). We obtained monoclonal antibodies against RalA, cell division cycle 42 (cdc42), and RacI from BD Biosciences (Mississauga, Ontario, Canada); Sec6 and Sec8 from StressGen (Victoria, British Columbia, Canada); syntaxin 1 (clone HPC-1) from Sigma (Oakville, Ontario, Canada); soluble $\mathrm{N}$-ethylmaleimide-sensitive factor (NSF) attachment protein-25 (SNAP25; clone SMI 81) and c-Myc (clone 9E10) from Covance (Berkeley, CA); rabbit polyclonal antibodies against RalB from BD Biosciences; and secretogranin II from QED Bioscience (San Diego, CA). Monoclonal antibodies against synaptobrevin 2 (Cl69.2) and Ras-associated binding protein 3A/3C (Rab3A/3C; Cl42.1) were a kind gift from Dr. Reinhard Jahn (Max Planck Institute for Biophysical Chemistry, Göttingen, Germany). Monoclonal antibodies against Sec5 and Exo84 were kind gifts from Dr. Jagath Junutula (Genentech, South San Francisco, CA), which were generated in Dr. Richard Scheller's laboratory (Genentech).

Construction of knock-down plasmids. To knock-down the rat RalA gene, we targeted the 19 nucleotide sequence of GACTACGCTGCAATTAGAG in RalA, and we targeted the 19 nucleotide sequence of GGTGGTTCTCGACGGAGAA in RalB to knock-down rat RalB. We used TTCAAGAGA as a linker sequence (Brummelkamp et al., 2002). Then 64 bp oligos containing sense and antisense of the target sequences were annealed and subcloned into the BamHI and HindIII site of pSuper, generating the RalA knock-down plasmid (pSuper-rRalA-2) and the RalB knock-down plasmid (pSuper-rRalB-3) (Brummelkamp et al., 2002; Ning et al., 2004). Inserted sequences were verified by sequencing.

Construction of expression plasmids. pCMV9E10myc-RalA has been described previously (Wang et al., 2004). To express Myc-RalA protein in the RalA/RalB double knock-down cells, we introduced six silent nucleotide mutations (SNMs) (GATTATGCAGCTATCAGGG; italics indicate SNMs) within the target sequence in RalA by using the Quikchange Site-Directed Mutagenesis kit (Stratagene, La Jolla, CA), resulting in pCMV9E10myc-RalA(SNM). Full-length RalB was synthesized by PCR from a rat brain cDNA library and subcloned into pCMVmyc (pCMVmyc-RalB). To express Myc-RalB in the double knock-down cells, we introduced seven silent nucleotide mutations (AGTCGTTCTAGATGGTGAG) within the target sequence in RalB, resulting in pCMVmyc-RalB(SNM). To measure secretion from transfected cells, we constructed a reporter plasmid (pCMV-NPY-hLAP) by which NPY fused with a soluble domain of human alkaline phosphatase (residues $18-506)$ is expressed. This plasmid was generated as follows: a $0.3 \mathrm{~kb}$ PCR fragment (coding cDNA for NPY) on pVenus-N1-NPY was digested with BglII/ClaI and subcloned into the BglII/ClaI site of pCMVemerald green fluorescent protein (pCMV-EmeraldGFP), generating pCMV-NPY-EmeraldGFP. Emerald GFP cDNA was replaced with cDNA, which encodes a soluble domain of human placental alkaline phosphatase (hPLAP) that was amplified by PCR and digested with ClaI/XbaI.

Isolation of stable PC12 cells in which RalA and RalB are stably downregulated. Wild-type PC12 cells [which were kind gifts from Dr. Thomas
Martin (University of Wisconsin, Madison, WI) and Dr. Erik Schweitzer, (University of California at Los Angeles, Los Angeles, CA)] were maintained in the DMEM (Invitrogen, Carlsbad, CA) containing 5\% calf serum, 5\% horse serum (both from HyClone, Logan, UT), and penicillin/ streptomycin (Sigma) (Schweitzer, 1993; Sugita et al., 2001, 2002; Wang et al., 2004, 2005; Li et al., 2005). To establish the RalA knock-down clone cells, we cotransfected PC12 cells with linearized pSuper-rRalA-2 (by SacI digestion; $10 \mu \mathrm{g}$ ) and pBabe-puro (by NotI digestion; $1 \mu \mathrm{g}$ ) using electroporation (Aikawa and Martin, 2003; Li et al., 2005) and maintained them in growth medium containing $2.5 \mu \mathrm{g} / \mathrm{ml}$ puromycin for $>1$ month. The growing colonies were picked up with pieces of Whatman paper soaked with Hank's buffer containing 1 mM EDTA. Isolated colonies were grown in the growth medium without puromycin in 24-well plates. When the cells became confluent, they were transferred into two wells of six-well plates that contained the growth medium with $2.5 \mu \mathrm{g} / \mathrm{m}$ of puromycin. The cells in one of the six-well plates were subjected to immunoblot analysis with an anti-RalA monoclonal antibody. Once the downregulation of RalA was confirmed, the cells in the replica wells were transferred into $10 \mathrm{~cm}$ dishes containing the growth medium with puromycin. These cells were grown, frozen, and kept in a liquid nitrogen tank until use.

To establish RalA/RalB double knock-down cells, we cotransfected the stable RalA knock-down cells (RalA ${ }^{\text {KD8 }}$, RalA ${ }^{\text {KD47 }}$ ) with pSuper-rRalB-3 (no linearization; $10 \mu \mathrm{g}$ ) and pcDNA3 $(1 \mu \mathrm{g})$ with the use of electroporation; they were maintained in growth medium with $1.0 \mathrm{mg} / \mathrm{ml} \mathrm{G} 418$ for $>1$ month. The stable clones were isolated similarly and analyzed by using polyclonal anti-RalB antibodies.

$\left[{ }^{3} \mathrm{H}\right]$-norepinephrine release assays using permeabilized PC12 cells. PC12 cells were labeled with $0.5 \mu \mathrm{Ci}\left[{ }^{3} \mathrm{H}\right]$-norepinephrine $\left(\left[{ }^{3} \mathrm{H}\right]-\mathrm{NE}\right.$; GE Healthcare, Baie d'Urfé, Québec, Canada) in the presence of $0.5 \mathrm{~mm}$ ascorbic acid. After being washed, the cells were harvested in K-Glu buffer [containing the following (in mM): 20 HEPES, pH 7.1, 120 potassium glutamate, 20 potassium acetate, and 2 EGTA] with $0.1 \%$ bovine serum albumin (BSA); the cells were permeabilized by freeze-thaw and were incubated for $1-3 \mathrm{~h}$ on ice in the presence of $10 \mathrm{~mm}$ EGTA to extract the cytosolic proteins (Wang et al., 2004). Permeabilized PC12 cells were washed three times with K-Glu buffer containing 0.1\% BSA. GTPdependent NE secretion assays were conducted in K-Glu buffer with $0.09 \%$ BSA containing various concentrations of guanyl- $5^{\prime}$-yl imidodiphosphate (GppNHp) (trisodium salt; Sigma) for $25 \mathrm{~min}$ at $30^{\circ} \mathrm{C}$. Different from $\mathrm{Ca}^{2+}$-dependent secretion (see below), GTP-dependent secretion does not require the presence of brain cytosol, and the addition of brain cytosol does not enhance GTP-dependent secretion (Klenchin et al., 1998; Wang et al., 2004). Thus brain cytosol was not added in GTPdependent secretion.

$\mathrm{Ca}^{2+}$-dependent secretion assays were performed in K-Glu buffer with $0.07 \%$ BSA and $2 \mathrm{~mm} \mathrm{Mg-ATP} \mathrm{with} \mathrm{or} \mathrm{without} 1 \mathrm{mg} / \mathrm{ml}$ brain cytosol and with or without $1.72 \mathrm{~mm} \mathrm{CaCl}_{2}$ for $25 \mathrm{~min}$ at $30^{\circ} \mathrm{C} \cdot \mathrm{CaCl}_{2}$ in K-Glu buffer $(1.72 \mathrm{~mm})$, which contains $2 \mathrm{~mm}$ EGTA, produced $\sim 1-3$ $\mu \mathrm{M}$ of free $\mathrm{Ca}^{2+}\left(\left[\mathrm{Ca}^{2+}\right]_{\text {free }}\right)$ (Chen et al., 1999). Secretion was terminated by chilling to $0^{\circ} \mathrm{C}$, and the samples were centrifuged at $4^{\circ} \mathrm{C}$ for 3 min. Supernatants were removed, and the pellets were solubilized in $1 \%$ Triton X-100 for liquid scintillation counting. In secretion assays with $\mathrm{Ca}^{2+}$ titration we stimulated secretion from permeabilized cells with 0.5 , $1,1.5,1.72$, and $2 \mathrm{~mm}$ of $\mathrm{Ca}^{2+}$ in the presence of 2 mM EGTA. $\left[\mathrm{Ca}^{2+}\right]_{\text {free }}$ was calculated via a program written by Dr. Jochen Kleinschmidt (New York University, New York, NY) (Wang et al., 2004) and estimated to be $0.07,0.2,0.6,1.3$, and $13.7 \mu \mathrm{M}$, respectively.

$\left[{ }^{3} \mathrm{H}\right]-\mathrm{NE}$ release assays using intact PC12 cells. PC12 cells were plated in 24-well plates; 3-4 d after plating the cells were labeled with $0.5 \mu \mathrm{Ci}$ [ $\left.{ }^{3} \mathrm{H}\right]$-NE in the presence of $0.5 \mathrm{~mm}$ ascorbic acid for $12-16 \mathrm{~h}$. The labeled PC12 cells were incubated with fresh complete DMEM for $1-5 \mathrm{~h}$ to remove unincorporated $\left[{ }^{3} \mathrm{H}\right]-\mathrm{NE}$. The cells were washed once with physiological saline solution (PSS) containing the following (in $\mathrm{mM}$ ): 145 $\mathrm{NaCl}, 5.6 \mathrm{KCl}, 2.2 \mathrm{CaCl}_{2}, 0.5 \mathrm{MgCl}_{2}, 5.6$ glucose, and $15 \mathrm{HEPES}, \mathrm{pH}$ 7.4. NE secretion was stimulated with $200 \mu$ l of PSS or high $\mathrm{K}^{+}$-PSS containing $81 \mathrm{~mm} \mathrm{NaCl}$ and $70 \mathrm{~mm} \mathrm{KCl}$. Secretion was terminated after a $15 \mathrm{~min}$ incubation at $37^{\circ} \mathrm{C}$ by chilling to $0^{\circ} \mathrm{C}$, and samples were centrifuged at 
$4^{\circ} \mathrm{C}$ for $3 \mathrm{~min}$. Supernatants were removed, and the pellets were solubilized in $0.1 \%$ Triton X-100 for liquid scintillation counting.

hPLAP secretion assay from permeabilized PC12 cells. PC12 cells at 70$80 \%$ confluency in $10 \mathrm{~cm}$ dishes were transfected with 3-13 $\mu \mathrm{g}$ of plasmid DNA via electroporation. After $72 \mathrm{~h}$ the cells were harvested with 6 $\mathrm{ml}$ of K-Glu buffer containing $0.1 \%$ BSA. Cells then were permeabilized with freeze-thaw and stimulated with $100 \mu \mathrm{l}$ of K-Glu buffer containing $0.09 \%$ BSA and the indicated concentrations of GppNHp for $25 \mathrm{~min}$ at $30^{\circ} \mathrm{C}$. The amounts of NPY-hPLAP secreted into the medium and retained in the cells were measured by the Phospha-Light Reporter Gene Assay System (Applied Biosystems, Foster City, CA). Briefly, the following were treated at $65^{\circ} \mathrm{C}$ for 30 min to inactivate nonplacental alkaline phosphatase: secreted NPY-hPLAP (in $100 \mu \mathrm{l}$ of K-Glu buffer), which was mixed with an equal volume of $\mathrm{K}$-Glu buffer containing $0.2 \%$ Triton $\mathrm{X}-100,10 \mathrm{~mm} \mathrm{CaCl}_{2}$, and $10 \mathrm{~mm} \mathrm{MgCl}_{2}$ and also cellular NPY-hPLAP (which was extracted with $200 \mu \mathrm{l}$ of K-Glu buffer containing $0.1 \%$ Triton $\mathrm{X}-100,5 \mathrm{~mm} \mathrm{CaCl}_{2}$, and $5 \mathrm{~mm} \mathrm{MgCl}_{2}$ ). Then we assayed an aliquot (10 $\mu l)$ for placental alkaline phosphatase activity with the kit. The total volume of the assay was $120 \mu \mathrm{l}$. After 5-10 min the chemiluminescence was quantified by an FB12 Luminometer (Berthold Detection Systems and Zylux, both located in Oak Ridge, TN).

Analysis of dense core vesicles by electron microscopy. Cells were grown in normal $10 \mathrm{~cm}$ Petri dishes to a confluence of $\sim 70 \%$ before being fixed. The chemical fixation was performed initially by fixing for $1 \mathrm{~h}$, using a $3.2 \%$ glutaraldehyde $2.5 \%$ paraformaldehyde mixture in $0.1 \mathrm{M}$ cacodylate buffer ( $\mathrm{pH}$-adjusted to 7.6). Cells then were scraped off the plates, transferred to microcentrifuge tubes, and centrifuged for $4 \mathrm{~min}$ at 4000 $\mathrm{rpm}$. The supernatant fixative was replaced with $1.5 \mathrm{ml}$ of new fixative, and the tubes then were incubated overnight at $4^{\circ} \mathrm{C}$. The next day the cells were centrifuged again, and the fixative was removed. The pellets were washed three times, for $10 \mathrm{~min}$ each time, with $1.5 \mathrm{ml}$ of $0.1 \mathrm{M}$ cacodylate buffer. Then the pellets were subjected to $1.5 \mathrm{ml}$ of $1 \mathrm{mg} / \mathrm{ml}$ osmium tetroxide for $2 \mathrm{~h}$. After another set of three washes with $1.5 \mathrm{ml}$ of cacodylate buffer, the pellets were washed twice with distilled water to remove traces of cacodylate buffer. Next the pellets were subjected to $1.5 \mathrm{ml}$ of uranyl acetate for $1 \mathrm{~h}$ in dark conditions. After two washes with water the pellets went through serial dehydration steps. First the pellets were incubated twice, for $10 \mathrm{~min}$ each time, in $1.5 \mathrm{ml}$ of $50 \%$ ethanol. This was followed by two similar incubations in 75\% ethanol and in 95\% ethanol. Finally, with three successive $10 \mathrm{~min}$ incubations in $1.5 \mathrm{ml}$ of $100 \%$ ethanol, the pellets were dehydrated completely. The pellets then were transferred to $5 \mathrm{ml}$ glass vials and incubated for $30 \mathrm{~min}$ at room temperature in $5 \mathrm{ml}$ of propylene oxide. The vials were mixed well during this time in preparation for the subsequent serial plastic infiltrations. Pellets next were incubated for $1 \mathrm{~h}$ in a 1:1 Epon Araldite plastic resin/propylene oxide mixture. Glass vials were well mixed during this time. After this the pellets were incubated overnight at $4^{\circ} \mathrm{C}$ in a $3: 1$ Epon Araldite plastic resin/propylene oxide mixture. This resin mixture was replaced the next day with 100\% Epon Araldite resin and mixed well at room temperature for $\sim 4-5$ h to allow for complete resin infiltration. Pellets were transferred to small BEEM capsules (Pesco International, Redding, CA) and supplemented with new $100 \%$ Epon Araldite resin. The capsules containing the pellets were incubated for $48 \mathrm{~h}$ at $60^{\circ} \mathrm{C}$. The plasticized pellets were sliced to ultrathin $80 \mathrm{~nm}$ sections, which then were mounted on copper grids for subsequent staining and viewing.

Grids mounted with the ultrathin cell sections first were etched by exposing the section on the grids to uranyl acetate for $15 \mathrm{~min}$ at room temperature. Then the grids were washed three times in distilled water for $5 \mathrm{~min}$ each time. After this the sections were stained with lead citrate for $20 \mathrm{~min}$ at room temperature. The grids again were washed three times in water and dried before loading onto a Hitachi (Tokyo, Japan) H7000 Transmission Electron Microscope for viewing. Then electron micrographs were taken of individual cells within each type of the RalA/RalB double knock-down clones and the control RalA single knock-down clones. These images were used for analyzing the docking of dense core vesicles.

NGF-induced neurite outgrowth in PC12 cells. The wild-type, the RalAsingle knock-down, and the double knock-down cells were plated in DMEM supplemented with $1 \%$ horse serum and $1 \%$ calf serum in $10 \mathrm{~cm}$
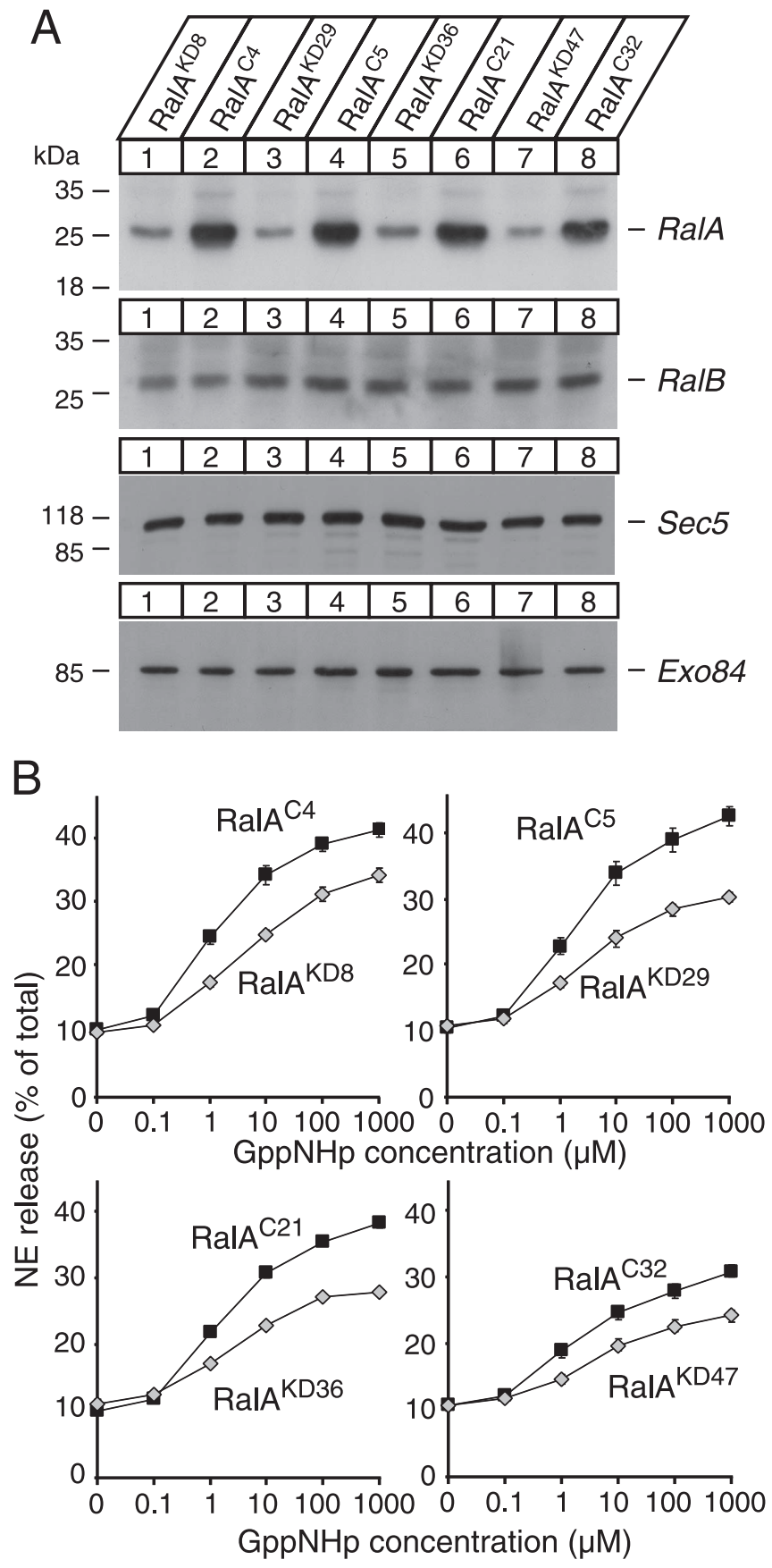

Figure 1. Downregulation of RalA results in a limited level of reductions in GTP-dependent exocytosis. A, Immunoblot analysis of RalA knock-down cells. Total homogenates (15 $\mu \mathrm{g}$ ) from the RalA knock-down (KD) and control (C) cells were analyzed by SDS-PAGE and immunoblotting, with the use of anti-RalA, anti-RaIB, anti-Sec5, and anti-Exo84 antibodies. Numbers on the left indicate positions of molecular weight markers. $\boldsymbol{B}, \mathrm{NE}$ release was stimulated by the indicated concentration of GppNHp from the permeabilized RalA knock-down cells (gray diamonds) and the paired control cells (black squares). Four pairs of RalA knock-down and control clones were examined. The error bars indicate SEM $(n=6) ; n$ represents the total number of samples tested in multiple experiments.

dishes at low density ( $\sim 10 \%$ confluency). Neurite outgrowth was induced with the addition of $100 \mathrm{ng} / \mathrm{ml} \mathrm{NGF}$, and medium containing the NGF was changed every other day.

Immunocytochemistry and confocal laser-scanning microscopy. The PC12 cells that were plated on poly-D-lysine-coated glass coverslips and in some cases differentiated by NGF were washed with PBS, fixed for 15 min with PBS containing 4\% paraformaldehyde, and permeabilized with 


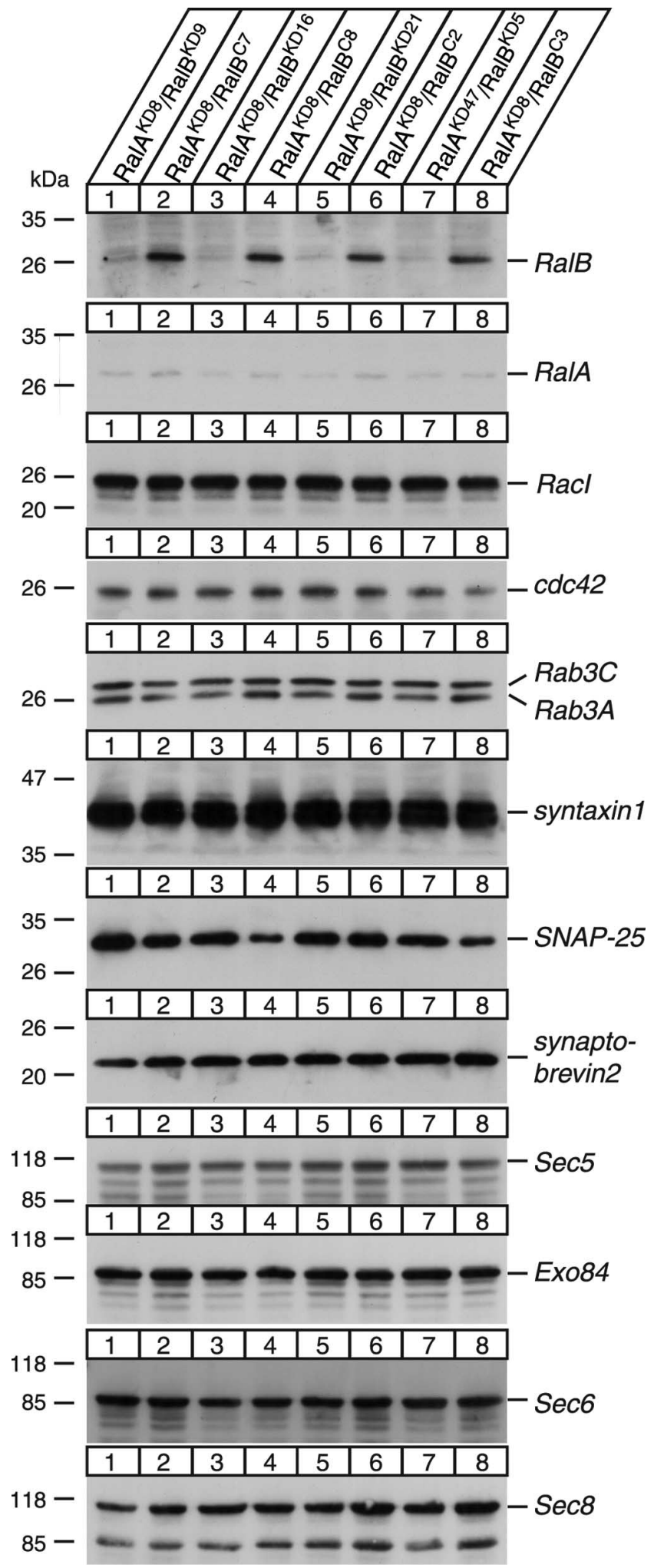

Figure 2. Immunoblot analysis of the expression of various proteins in the RaIA/RalB double knock-down cells. Total homogenates $(15 \mu \mathrm{g})$ from the RaIA/RalB double knock-down cells and the control RalA single knock-down cellswere analyzed by SDS-PAGE and immunoblotting with the use of the antibodies listed on the right. Numbers on the left indicate positions of molecular weight markers.

PBS containing $0.2 \%$ Triton X-100 and $0.3 \%$ BSA for 5 min. Nonspecific sites were blocked for $1 \mathrm{~h}$ at room temperature in PBS containing $0.3 \%$ BSA. Primary antibodies against Myc (mouse ascites diluted 1:500) and/or secretogranin II (rabbit polyclonal antiserum diluted 1:1000)
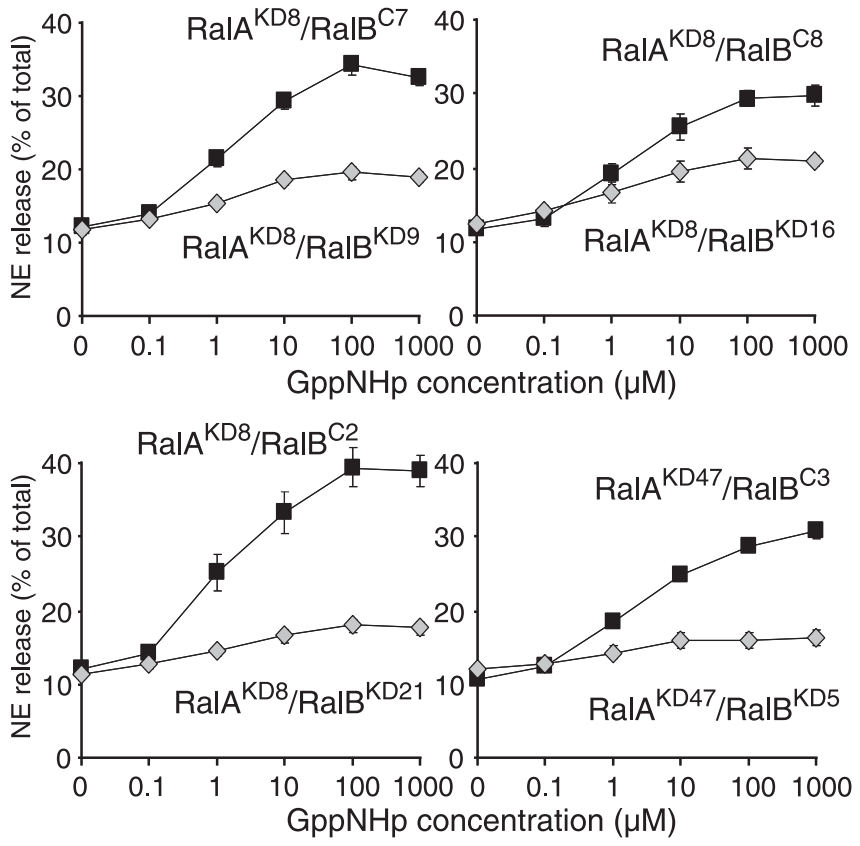

Figure 3. RalA/RalB double knock-down cells exhibit strong reductions in GTP-dependent exocytosis. Permeabilized RalA/RalB double knock-down cells (gray diamonds) and paired RalA single knock-down cells (black squares) were stimulated for NE release by using the indicated concentrations of GppNHp. Four pairs of the RalA/RalB double knock-down clones and the control RalA single knock-down clones were examined. The error bars indicate SEM $(n=6-8)$.

were diluted in blocking buffer and applied to the permeabilized cells for $1 \mathrm{~h}$ at room temperature. After three washes in blocking buffer, goat Alexa 488-conjugated anti-mouse antibodies (diluted 1:1000) and goat Alexa 568-conjugated anti-rabbit antibodies (diluted 1:1000) (both from Invitrogen) were diluted in blocking buffer and applied for $1 \mathrm{~h}$ at room temperature. Samples were washed again three times in blocking buffer and mounted in Fluoromount-G reagent (Southern Biotechnology, Birmingham, AL). Immunofluorescence staining was recorded with a Zeiss (Toronto, Ontario, Canada) laser confocal-scanning microscope (LSM $510)$ with an oil immersion objective lens $(63 \times)$.

\section{Results}

Downregulation of RalA results in limited reduction of GTP-dependent exocytosis

To elucidate the role of endogenous RalA for GTP-dependent exocytosis, we first generated stable PC12 cell lines in which the expression of RalA is strongly downregulated by RNA interference, using the method of Brummelkamp et al. (2002). We cotransfected PC12 cells with the plasmid that expresses a shorthairpin RNA against rat RalA mRNA (pSuper-rRalA-2; $10 \mu \mathrm{g}$ ) and the plasmid that confers puromycin resistance (pBabe-puro; $1 \mu \mathrm{g})$. Independent colonies of stable transfectants of PC12 cells were isolated after incubation with puromycin $(2.5 \mu \mathrm{g} / \mathrm{ml})$ for $>1$ month, and the level of the downregulation of RalA in each colony was analyzed with immunoblotting. We successfully isolated several independent clone cells that exhibited strong reductions in RalA (Fig. 1A). Control clones were isolated similarly, but an empty pSuper plasmid was used instead of pSuperrRalA-2 for cotransfection with pBabe-puro. At no time did we observe the reduction of RalA expression in the control clones. The knock-down by pSuper-RalA-2 appeared to be specific to RalA, because the expression of RalB was unaffected in the RalA knock-down cells (Fig. 1 $A$ ). We also did not observe any changes in the level of Sec5 or Exo84 in the RalA knock-down cells. Sec5 and Exo84 are components of the exocyst complex that physically 

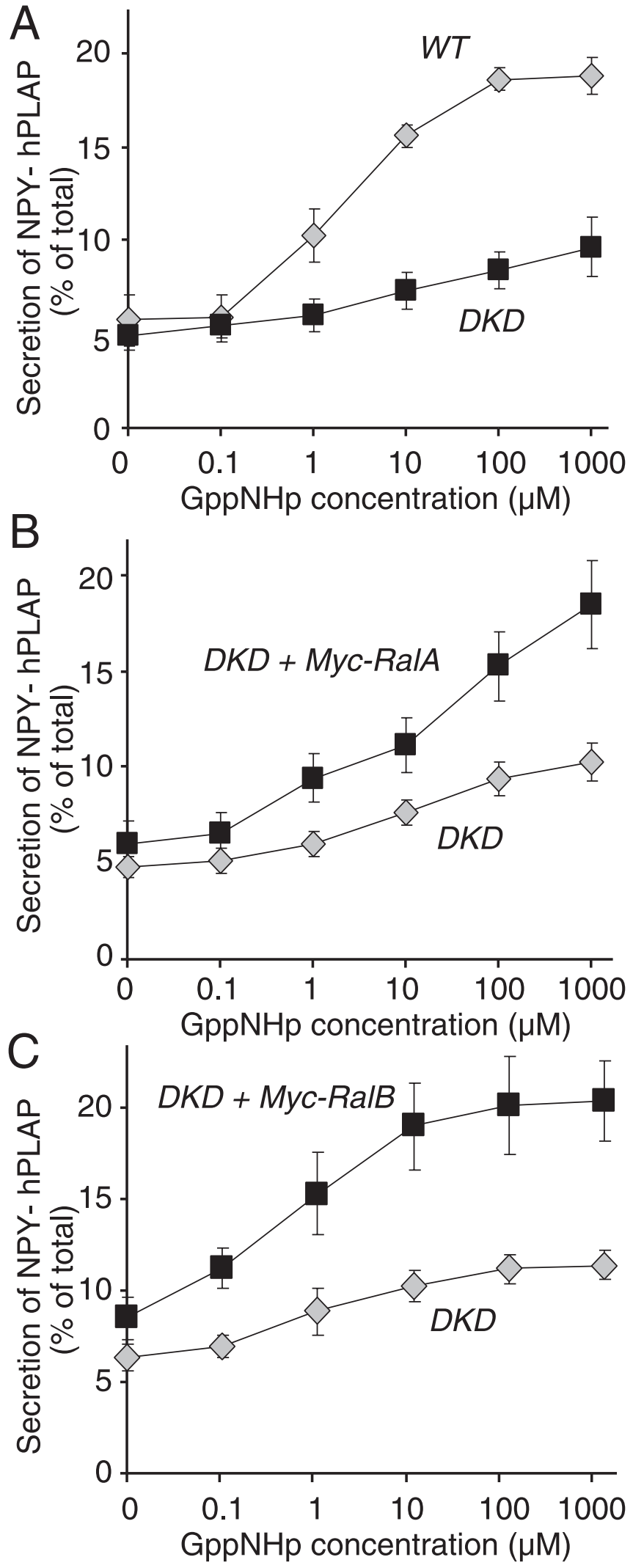

Figure 4. Transfection of RalA or RalB restores GTP-dependent exocytosis in the RalA/RalB double knock-down cells. $\boldsymbol{A}$, Secretion of transfected NPY-hPLAP was stimulated with the indicated concentrations of GppNHp from wild-type PC12 cells (WT; gray diamonds) or RalA/RalB double knock-down (RalA ${ }^{\mathrm{KD} 8} / \mathrm{RaIB}^{\mathrm{KD} 9}$ ) cells (DKD; black squares). The error bars indicate SEM $(n=6) . B$, GppNHp-induced secretion of NPY-hPLAP from the double knock-down cells transfected with Myc-RalA (DKD plus Myc-RalA; black squares) or a control vector (DKD; gray diamonds). The transfected cells were permeabilized and stimulated with the indicated concen- interacts with RalA and RalB in a GTP-dependent manner (Moskalenko et al., 2002, 2003; Sugihara et al., 2002).

We then analyzed GTP-dependent secretion of NE from the four stable RalA knock-down (KD) cells (RalA ${ }^{\mathrm{KD} 8}$, $\mathrm{RalA}^{\mathrm{KD} 29}$, RalA $^{\mathrm{KD} 36}$, RalA ${ }^{\mathrm{KD} 47}$ ) together with four control (C) cells (Ra$1 A^{\mathrm{C} 4}$, RalA ${ }^{\mathrm{C} 5}$, RalA ${ }^{\mathrm{C} 21}, \mathrm{RalA}^{\mathrm{C} 32}$ ). Because it is not technically feasible to measure secretion from all four pairs of cell lines simultaneously, we paired the knock-down and the control cells and conducted the secretion assay simultaneously for each pair. Simultaneous measurements of secretion from each pair would minimize variations derived from experimental procedures. $\left[{ }^{3} \mathrm{H}\right]$-NE-labeled cells were permeabilized with freeze-thaw, and the release of $\left[{ }^{3} \mathrm{H}\right]$-NE was stimulated directly by increased concentrations of GppNHp (see Materials and Methods). We found consistent reduction of GTP-dependent exocytosis in the RalA knock-down cells when we compared them with control cells (Fig. $1 B$ ). For each pair the GppNHp-induced (1 mM) NE release was reduced significantly in RalA knock-down clones as compared with control clones ( $p<0.01$; analyzed by Student's $t$ test). Nevertheless, the inhibition was limited to $\sim 20-30 \%$ of the GTP-dependent exocytosis in the controls cells. In contrast, we have found previously that dominant-negative, soluble RalA can inhibit GTP-dependent exocytosis by 70\% (Wang et al., 2004).

\section{Isolation of the stable cell lines in which RalA and RalB are} strongly downregulated

Although the level of downregulation in RalA was not 100\% (Fig. $1 A)$, this did not seem to explain its limited inhibition. We hypothesized that this limited effect is a result of the presence of RalB in PC12 cells (Fig. 1A). Similar to RalA, RalB interacts with the exocyst complex (Moskalenko et al., 2002; Sugihara et al., 2002) and can be involved in GTP-dependent exocytosis. As a consequence, we attempted to isolate the stable double knockdown cells in which both RalA and RalB are downregulated (Fig. 2). To do this, we cotransfected two of the RalA knock-down cells (RalA ${ }^{\mathrm{KD} 8}$, RalA ${ }^{\mathrm{KD} 47}$ ) with an RalB knock-down plasmid (pSuper-rRalB-3; $10 \mu \mathrm{g})$ and pcDNA3 $(1 \mu \mathrm{g})$, which confer resistance to G418. Stable transfectants were isolated after incubation with G418 (1 mg/ml) for $>1$ month, and the level of downregulation of RalB in each colony was analyzed by immunoblotting. Using the results of the blot, we could isolate several independent clone cells in which both RalA and RalB are downregulated stably (Fig. 2). For the control the RalA knock-down cells were cotransfected with an empty knock-down plasmid (pSuper; $10 \mu \mathrm{g}$ ) and pcDNA3 $(1 \mu \mathrm{g})$. Control clones that have RalA knock-down only were isolated similarly (Fig. 2). During the process of isolation of the double knock-down clones and the control clones we did not incubate the cells with puromycin. Nevertheless, we did not observe the recovery of the expression of RalA in the isolated clones, which indicates that downregulation of RalA is stable for at least 2 months (Fig. 2).

We compared the expression levels of various proteins between the RalA/RalB double knock-down cells and the control RalA single knock-down cells (Fig. 2). We did not see any consistent changes between them in the expression of the neuronal SNAP receptor (SNARE) proteins, namely synaptobrevin 2,

$\leftarrow$

trations of GppNHp. The error bars indicate SEM $(n=8)$. C, GppNHp-induced secretion of NPY-hPLAP from the double knock-down cells transfected with pCMVmyc-rRalB(SNM) (DKD plus Myc-RalB; black squares) or a control vector (DKD; gray diamonds). The transfected cells were permeabilized and stimulated with the indicated concentrations of GppNHp. The error bars indicate SEM $(n=6)$. 
A
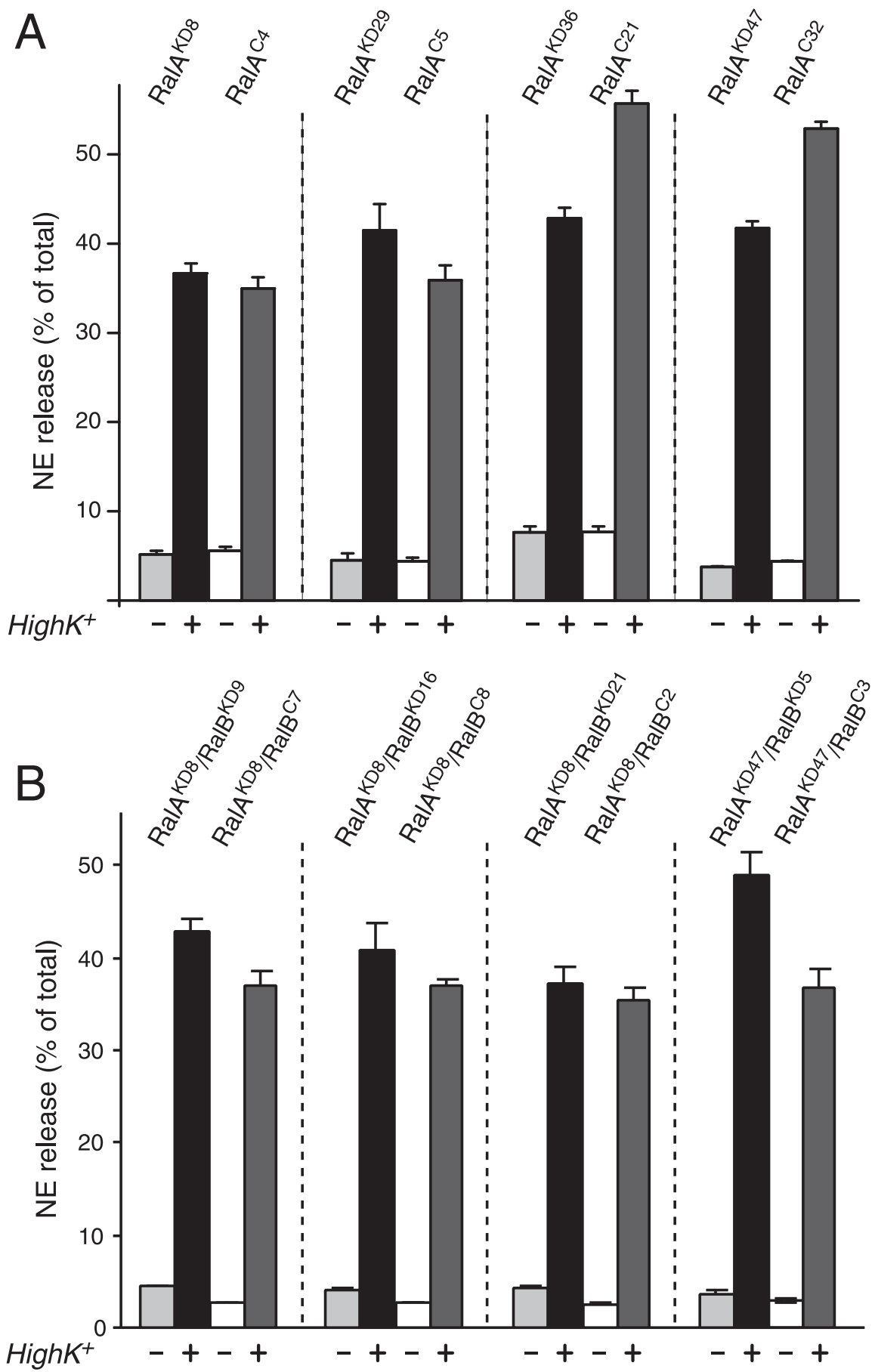

Figure 5. Downregulation of RalA and RalB has no effect on High $\mathrm{K}^{+}$-stimulated $\mathrm{Ca}^{2+}$-dependent exocytosis. $\boldsymbol{A}$, NE release from the RalA knock-down cells and the control cells was stimulated by a 15 min incubation with control $\mathrm{K}^{+}$solution $(5.6 \mathrm{~mm} ;-)$ or high $\mathrm{K}^{+}$solution $(70 \mathrm{~mm} ;+)$. Four pairs of the clones were examined. The error bars indicate SEM $(n=6-15)$. $\boldsymbol{B}$, NE release from the RalA/RalB double knock-down cells and the RalA single knock-down cells was stimulated with a 15 min incubation with control $\mathrm{K}^{+}$solution $(5.6 \mathrm{~mm} ;-)$ or high $\mathrm{K}^{+}$solution $(70 \mathrm{~mm} ;+)$. Four pairs of the clones were examined. The error bars indicate $\operatorname{SEM}(n=9-12)$.

SNAP-25, and syntaxin 1, which are essential for membrane fusion or exocytosis (Sollner et al., 1993). We also did not see changes of other small GTPases, including RacI (Polakis et al., 1989), cdc42 (Munemitsu et al., 1990), and Rab3A/3C (Fischer von Mollard et al., 1990). Furthermore, we observed no changes in the expression level of the exocyst proteins, Sec5, exo84, Sec6, or Sec8 (Fig. 2). In summary, we isolated stable cell lines in which RalA and RalB are downregulated specifically, and there were no apparent compensatory changes in the expression of other proteins.

Downregulation of both RalA and RalB results in severe reduction of GTP-dependent exocytosis

We then analyzed the GTP-dependent NE release from the double knock-down cells. The double knock-down cells (RalA ${ }^{\mathrm{KD} 8}$ / $\mathrm{RalB}^{\mathrm{KD} 9}$, RalA ${ }^{\mathrm{KD} 8} / \mathrm{RalB}^{\mathrm{KD} 16}, \mathrm{RalA}^{\mathrm{KD} 8}$ / $\mathrm{RalB}^{\mathrm{KD} 21}, \mathrm{RalA}^{\mathrm{KD} 47} / \mathrm{RalB}^{\mathrm{KD} 5}$ ) were paired with the control RalA single knock-down cells $\left(\mathrm{RalA}^{\mathrm{KD} 8} / \mathrm{RalB}^{\mathrm{C} 7}\right.$, RalA ${ }^{\mathrm{KD}} / \mathrm{RalB}^{\mathrm{C} 8}$, $\mathrm{RalA}^{\mathrm{KD} 8} / \mathrm{RalB}^{\mathrm{C} 2}$, $\mathrm{RalA}^{\mathrm{KD} 47} / \mathrm{RalB}^{\mathrm{C} 3}$ ), and $\left[{ }^{3} \mathrm{H}\right]$-NE release was examined by various concentrations of GppNHp. For all of the pairs we found that the GTP-dependent release of $\left[{ }^{3} \mathrm{H}\right]-\mathrm{NE}$ was reduced severely in the double knock-down cells when we compared them with the RalA single knock-down cells (Fig. 3). At $1 \mathrm{~mm}$ of GppNHp the inhibition was statistically significant ( $p<0.01$; analyzed by Student's $t$ test) for each pair. These results indicate that RalA and RalB are the major GTP sensors for GTP-dependent exocytosis. They also suggest that the presence of either isoform is mostly sufficient to execute GTPdependent exocytosis. Because the efficacy of the knock-down of target proteins was not $100 \%$ (Fig. 2), we could not determine whether the residual GTP-dependent exocytosis is attributable to the contributions of other GTPases or to the residual activities of RalA/RalB GTPases.

\section{Expression of RalA or RalB in the double knock-down cells restores GTP-dependent exocytosis}

To examine whether the reduction of GTP-dependent exocytosis is truly attributable to the downregulation of RalA and RalB, we conducted rescue experiments. Because the transfection rate in PC12 cells is low, we used a reporter protein for transfection (Sugita et al., 1999; Sugita, 2004; Wang et al., 2004) in these rescue assays. We have generated a novel reporter plasmid (pCMV-NPY-hPLAP) by which NPY that is fused with a soluble domain (residues 18-506) of hPLAP is expressed. When we used the quantitative secretory alkaline phosphatase assay kit (see Materials and Methods), NPY-hPLAP secreted from the cells and retained in the cells was quantified easily by measurements of the heat-stable $\left(65^{\circ} \mathrm{C}\right)$ alkaline phosphatase activity of hPLAP. Thus NPY-hPLAP can be an ideal reporter for transfection to examine the effect of the transfected protein on secretion. In fact, we found that secretion of transfected NPY-hPLAP from PC12 cells was stimulated strongly by $70 \mathrm{~mm} \mathrm{KCl} \mathrm{(8.4 \%} \mathrm{secretion} \mathrm{of} \mathrm{total} \mathrm{NPY-hPLAP} \mathrm{with} 4.7 \mathrm{~mm}$ $\mathrm{KCl}$ vs $26.3 \%$ of total with $70 \mathrm{~mm} \mathrm{KCl})(n=3)$, which indicates that secretion of NPY-hPLAP is controlled by $\mathrm{Ca}^{2+}$. In addition, 
secretion of NPY-hPLAP from the wildtype PC12 cells also was stimulated by increased concentrations of GppNHp, similar to $\left[{ }^{3} \mathrm{H}\right]-\mathrm{NE}$ (Fig. 4A, labeled WT). GTP-dependent secretion of NPY-hPLAP was reduced dramatically in the double knock-down $\left(\mathrm{RalA}^{\mathrm{KD} 8} / \mathrm{RalB}^{\mathrm{KD} 9}\right)$ cells (Fig. 4A, labeled DKD). At $1 \mathrm{~mm} \mathrm{GppNHp}$ significant differences in secretion of NPY-hPLAP were detected between the wild-type and the double knock-down cells (unpaired Student's $t$ test; $t_{10}=5.40$; $p<0.01$ ). Thus the results of secretion assays using NPY-hPLAP as a neurotransmitter are consistent with those of secretion assays using $\left[{ }^{3} \mathrm{H}\right]-\mathrm{NE}$.

To examine whether either RalA or RalB expression by transfection can restore GTP-dependent secretion of NPYhPLAP in the RalA/RalB double knockdown cells, we cotransfected the RalA ${ }^{\mathrm{KD} 8}$ / RalB $^{\text {KD9 }}$ cells with pCMV-NPY-hPLAP (3 $\mu \mathrm{g})$ as well as the expression construct for RalA [pCMV9E10myc-RalA(SNM)] (10 $\mu \mathrm{g})$ or the construct for RalB [pCMVmyc$\mathrm{RalB}(\mathrm{SNM})]$ (10 $\mu \mathrm{g})$. So that RalA (or RalB) can be expressed in the double knock-down cells, these expression constructs contain silent nucleotide mutations (SNMs) in the RalA or RalB target sequence of the knockdown plasmids (see Materials and Methods). Also, to assess the localization of the transfected RalA and RalB proteins, we tagged those transfected RalA and RalB with a Myc sequence at the $\mathrm{N}$ terminus. As a control transfection the $\mathrm{RalA}^{\mathrm{KD}} / \mathrm{RalB}^{\mathrm{KD}}$ cells were cotransfected with pCMV-NPYhPLAP $(3 \mu \mathrm{g})$ and an empty plasmid pCMV5 $(10 \mu \mathrm{g})$. We found that transfection of RalA or RalB mostly restored the GTPdependent release of NPY-hPLAP from the RalA/RalB double knock-down (DKD) cells (Fig. 4 B, C). At $1 \mathrm{~mm} \mathrm{GppNHp} \mathrm{the} \mathrm{effect} \mathrm{was}$ statistically significant (unpaired Student's $t$ test; for RalA transfection, $t_{14}=3.46$ and $p<$ 0.01 ; for RalB transfection, $t_{10}=4.26$ and $p<0.01)$. Our results suggest that reduction of GTP-dependent exocytosis in the double knock-down cells is indeed attributable to the downregulation of RalA and RalB proteins, rather than the knock-down of unrelated proteins.

\section{Downregulation of RalA/RalB has little or no effect on $\mathrm{Ca}^{2+}$-dependent exocytosis}

The relationship between GTP-dependent and $\mathrm{Ca}^{2+}$-dependent exocytosis has not been understood fully. Using clostridial neurotoxins that cleave neuronal SNARE proteins (syntaxin 1, SNAP-25, synaptobrevin 2), we and others have demonstrated that these two forms of exocytosis are SNARE-dependent (Banerjee et al., 1996; Glenn and Burgoyne, 1996; Wang et al., 2004). However, we also found that inhibitors of GTP-dependent exocytosis, namely GDP, soluble recombinant RalA, or the Sec5 frag-
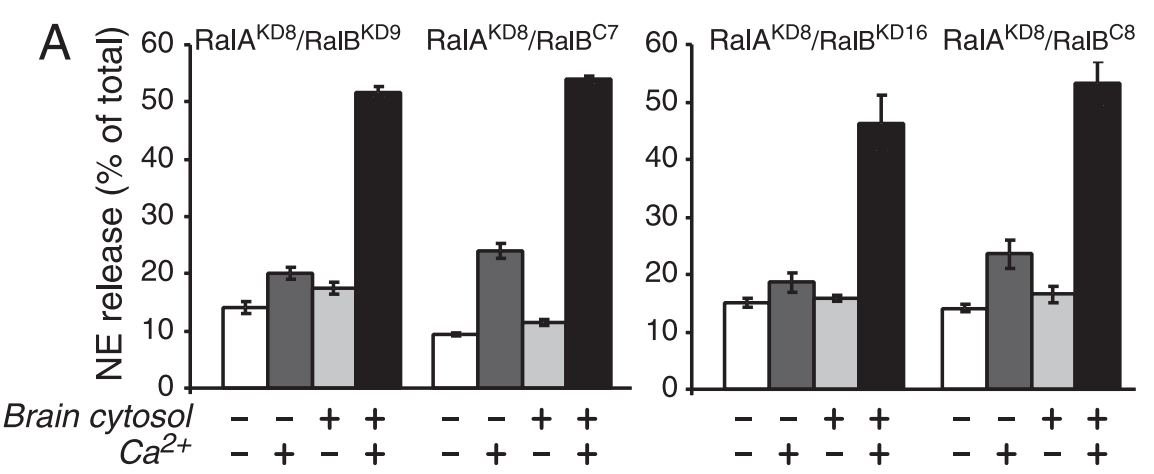

Figure 6. Downregulation of RalA and RalB has no effect on $\mathrm{Ca}^{2+}$-dependent exocytosis from permeabilized PC12 cells. $\boldsymbol{A}$, The RaIA/RalB double knock-down cells and the paired RalA single knock-down cells were permeabilized and incubated for NE release in the presence and absence of $\mathrm{Ca}^{2+}$ with and without brain cytosol. Four pairs of the clones were examined. The error bars indicate SEM $(n=6) . B, \mathrm{Ca}^{2+}$ titration of NE release from permeabilized wild-type PC12 cells (WT; open diamonds), RalA single knock-down (RaIA ${ }^{\mathrm{KD} 8} /$ RaIB $^{\mathrm{C7}}$ ) cells (RalAKD; gray squares), and RalA/RalB double knock-down (RalA ${ }^{\mathrm{KD} 8} / \mathrm{RaIB}^{\mathrm{KD} 9}$ ) cells (DKD; black squares). The error bars indicate SEM $(n=5)$.

ment that binds RalA, have no inhibitory effect on $\mathrm{Ca}^{2+}$ dependent exocytosis (Wang et al., 2004). These results suggest that GTP-dependent and $\mathrm{Ca}^{2+}$-dependent exocytosis use independent sensors and effectors before converging into a SNAREdependent fusion step and that RalA (or RalB) may not involved in $\mathrm{Ca}^{2+}$-dependent exocytosis. On the other hand, two recent papers suggest the involvement of RalA and/or RalB in $\mathrm{Ca}^{2+}$ dependent exocytosis, although these two papers reached opposite conclusions (Moskalenko et al., 2002; Vitale et al., 2005).

To clarify these disputes, we examined the effect of stable downregulation of RalA or RalA plus RalB on $\mathrm{Ca}^{2+}$-dependent exocytosis. We measured $\mathrm{Ca}^{2+}$-dependent exocytosis by using 


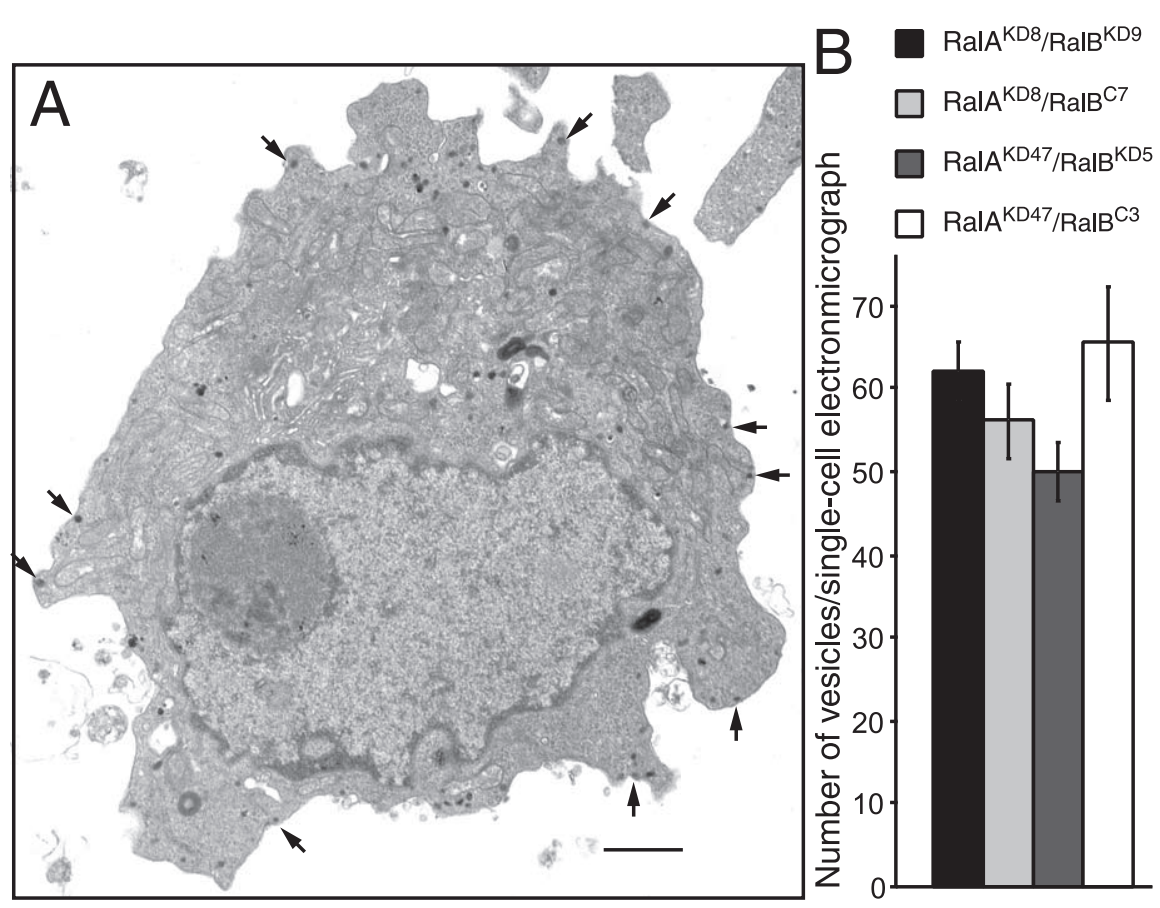

C

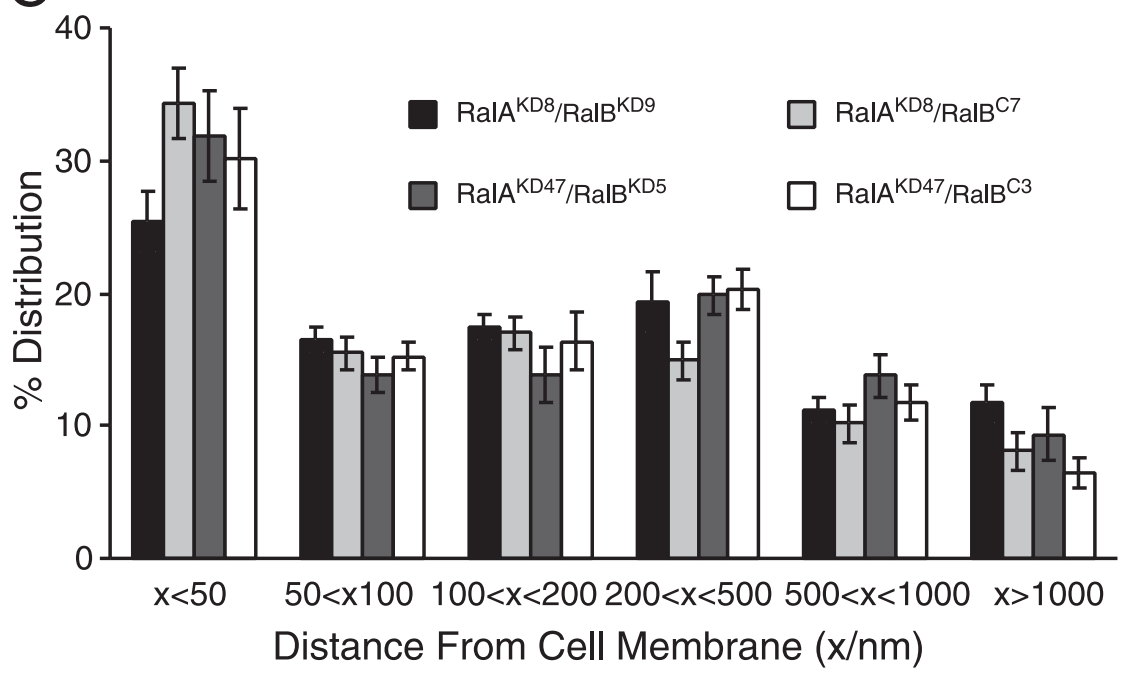

Figure 7. Electron microscopy of the RalA/RalB double knock-down cells does not reveal abnormalities in dense core vesicles. $\boldsymbol{A}$, Electron micrograph of a single cell from RalA/RalB double knock-down (RalA ${ }^{\mathrm{KD} 8} / \mathrm{RaIB}^{\mathrm{KD} 9}$ ) clones. Arrows indicate examples of dense core vesicles that are localized near the plasma membrane. Scale bar, $1 \mu \mathrm{m}$. $\boldsymbol{B}$, The graph shows the mean number of vesicles present in each single-cell electron micrograph from the four different clones (two double knock-down clones and two RalA single knock-down clones). The error bars indicate SEM ( $n=20-35)$. C, The graph shows the mean percentage distribution of dense core vesicles within individual PC12 cells, calculated from multiple single-cell electron micrographs from four different clones. Dense core vesicles were classed as being located within 50, 50-100, 100-200, 200-500, and 500-1000 nm as well as $>1000 \mathrm{~nm}$ from the plasma membrane. The error bars indicate SEM.

two different assays. One assay measures $\left[{ }^{3} \mathrm{H}\right]-\mathrm{NE}$ release from intact cells that are stimulated by high $\mathrm{K}^{+}(70 \mathrm{~mm})$ (Fig. $5)$, and the other assay measures $\left[{ }^{3} \mathrm{H}\right]-\mathrm{NE}$ release from permeabilized cells that are exposed directly to $\mathrm{Ca}^{2+}(\sim 1-10 \mu \mathrm{M}$ free $\mathrm{Ca}^{2+}$ ) (Fig. 6). In high $\mathrm{K}^{+}$-stimulated exocytosis we first compared the secretion between the control and the RalA single knock-down cells. We found that all four RalA single knock-down cells (RalA ${ }^{\mathrm{KD} 8}$, RalA ${ }^{\mathrm{KD} 29}$, RalA ${ }^{\mathrm{KD} 36}$, and $\mathrm{RalA}^{\mathrm{KD} 47}$ ) exhibited robust $\mathrm{Ca}^{2+}$-dependent $\left[{ }^{3} \mathrm{H}\right]-\mathrm{NE}$ secretion $\left(35-45 \%\right.$ of total $\left.\left[{ }^{3} \mathrm{H}\right]-\mathrm{NE}\right)$. Although in two pairs the control ( RalA $^{\mathrm{C} 21}$ and RalA ${ }^{\mathrm{C} 32}$ ) cells exhibited higher secretion than the paired RalA knock-down (RalA ${ }^{\mathrm{KD} 36}$ and RalA ${ }^{\mathrm{KD} 47}$ ) cells, this was attributable to unusually high competence of secretion ( $>50 \%$ of total) in the specific control cells. There was no consistent difference between the RalA knock-down and the control cells (Fig. $5 A)$. We also examined the secretion between the RalA/RalB double knockdown cells and the control RalA single knock-down cells. All four RalA/RalB double knock-down cells (RalA ${ }^{\mathrm{KD} 8}$ / $\mathrm{RalB}^{\mathrm{KD} 9}, \mathrm{RalA}^{\mathrm{KD} 8} / \mathrm{RalB}^{\mathrm{KD} 16}, \mathrm{RalA}^{\mathrm{KD} 8}$ / $\mathrm{RalB}^{\mathrm{KD} 21}$, RalA ${ }^{\mathrm{KD} 47} / \mathrm{RalB}^{\mathrm{KD} 5}$ ) exhibited robust $\mathrm{Ca}^{2+}$-dependent $\left[{ }^{3} \mathrm{H}\right]$-NE secretion, which was not different from the paired control RalA single knock-down cells $\left(\mathrm{RalA}^{\mathrm{KD} 8} / \mathrm{RalB}^{\mathrm{C} 7}, \mathrm{RalA}^{\mathrm{KD} 8} / \mathrm{RalB}^{\mathrm{C} 8}, \mathrm{RalA}^{\mathrm{KD} 8}\right.$ / $\mathrm{RalB}^{\mathrm{C} 2}, \mathrm{RalA}^{\mathrm{KD} 47} / \mathrm{RalB}^{\mathrm{C} 3}$ ) (Fig. 5B).

The significantly reduced GTP-dependent secretion in the double knock-down cells might be related to the permeabilization procedure; that is, the double knock-down cells might be more susceptible to permeabilization than the control cells and lose secretion capabilities in general after permeabilization. To exclude this possibility, we also measured $\mathrm{Ca}^{2+}$-dependent secretion from the permeabilized double knock-down cells and compared it with that from the RalAsingle knock-down cells. In the secretion assays that use permeabilized cells, we found that the RalA/RalB double knock-down cells, as well as the RalA single knock-down cells, exhibit robust $\mathrm{Ca}^{2+}$-dependent $\left[{ }^{3} \mathrm{H}\right]$ $\mathrm{NE}$ secretion that is dependent on brain cytosols (Fig. 6A). The brain cytosol provides the permeabilized cells with cytosolic proteins, including phosphatidylcholine transfer protein (Hay and Martin, 1993), phosphatidylinositol 4-phosphate 5-kinases (Hay et al., 1995; Aikawa and Martin, 2003; Wang et al., 2005), and $\mathrm{Ca}^{2+}$-dependent activator protein for secretion (Walent et al., 1992). To analyze additionally the $\mathrm{Ca}^{2+}$ dependence in secretion from the RalA/RalB double knock-down ( $\mathrm{RalA}^{\mathrm{KD} 8} / \mathrm{RalB}^{\mathrm{KD} 9}$ ) cells (Fig. 6B, labeled DKD) and the RalA single knock-down (RalA $\left.{ }^{\mathrm{KD} 8} / \mathrm{RalB}^{\mathrm{C} 7}\right) \quad$ cells (RalAKD), we titrated free $\mathrm{Ca}^{2+}$ concentrations with $\mathrm{Ca}^{2+} /$ EGTA buffers in $\left[{ }^{3} \mathrm{H}\right]-\mathrm{NE}$ secretion from these knock-down cells. We found no difference in $\mathrm{Ca}^{2+}$ dependence between the RalA single knock-down cells and the double knock-down cells. Furthermore, their $\mathrm{Ca}^{2+}$ dependence is similar to that of the wild-type PC12 cells (Fig. 6B, labeled WT). Overall, our results strongly suggest that $\mathrm{Ca}^{2+}$-dependent secretion is unimpaired in the RalA/RalB knockdown cells, even after the permeabilization procedure. Thus we conclude that RalA and RalB are not involved critically in $\mathrm{Ca}^{2+}$ dependent exocytosis. Our results also suggest that the inhibition of GTP-dependent exocytosis by RalA/RalB double knock-down is not the result of defects in general secretory apparatus but rather related specifically to the defects in sensing GTP. 
Downregulation of RalA and RalB has no or little effect on the docking of dense core vesicles

The exocyst proteins have been postulated to be critical for tethering the vesicles to the plasma membrane (Tsuboi et al., 2005). Because the exocyst proteins are critical effectors for RalA and RalB GTPases, it is reasonable to speculate that downregulation of RalA/RalB may result in perturbation of the docking of dense core vesicles. On the other hand, no defects on $\mathrm{Ca}^{2+}$-dependent exocytosis in the double knock-down cells (Figs. 5, 6) would suggest that RalA/RalB is not required for the docking of dense core vesicles. Here we use the term "docking" as the anatomical definition to refer to the phenomenon of secretory vesicles in close apposition to the plasma membrane. To examine the roles of RalA and RalB for docking of the vesicles, we directly examined the morphology of two of the RalA/RalB double knock-down cells ( $\mathrm{RalA}^{\mathrm{KD} 8} / \mathrm{RalB}^{\mathrm{KD}}$, $\mathrm{RalA}^{\mathrm{KD} 47} / \mathrm{RalB}^{\mathrm{KD} 5}$ ) together with two of the control RalA single knock-down cells ( RalA $^{\mathrm{KD} 8} / \mathrm{RalB}^{\mathrm{C} 7}$, $\mathrm{RalA}^{\mathrm{KD} 47} / \mathrm{RalB}^{\mathrm{C} 3}$ ) by electron microscopy. We did not detect morphological abnormalities in the double knock-down cells (Fig. 7A). We also found a similar number of the dense core vesicles between the double and single knock-down cells, which was $\sim 60$ vesicles per each single-cell electron micrograph (Fig. $7 B)$. We then quantitatively analyzed the positions and the numbers of the dense core vesicles in the double knock-down cells and the control RalA single knock-down cells. In all four clone cells $\sim 25-35 \%$ of dense core vesicles were localized within $50 \mathrm{~nm}$ from the plasma membrane, and there were no significant differences among them (Fig. 7C). In our previous set of the experiments we found that $\sim 35 \%$ of the dense core vesicles are localized within $50 \mathrm{~nm}$ from the plasma membrane in the wild-type PC12 cells (data not shown). Thus we conclude that RalA and RalB are not essential for biogenesis or morphological docking of the dense core vesicles. However, our results do not exclude the possibility that the vesicles are close but no longer tethered to the membrane in the absence of Ral proteins.

\section{Double knock-down of RalA/RalB shows no inhibition on neurite outgrowth}

Recently, it was suggested that the transient knock-down of RalA and/or RalB regulates the branching of cortical neurons that are dependent on growth cone-associated protein-43 (GAP-43) and the exocyst complex (Lalli and Hall, 2005). PC12 cells are a well established model of neurite outgrowth, which is induced by NGF (Greene and Tischler, 1976) and accompanied by increases in GAP-43 expression (Irwin et al., 2002). Therefore, we examined whether the downregulation of RalA and RalB inhibits NGFinduced neurite extension. We incubated the wild-type PC12 cells (Fig. 8, labeled WT), RalA single knock-down (Fig. 8, $\mathrm{RalA}^{\mathrm{KD} 8} / \mathrm{RalB}^{\mathrm{C} 7}$, labeled RalAKD) cells, and RalA/RalB double knock-down (Fig. 8, RalA ${ }^{\mathrm{KD} 8} / \mathrm{RalB}^{\mathrm{KD} 9}$, labeled DKD) cells with $100 \mathrm{ng} / \mathrm{ml}$ NGF for $5 \mathrm{~d}$. We found that the double knock-down cells extended neurites in response to NGF and exhibited no less than the responses of the wild-type or the RalA single knockdown cells (Fig. 8). Thus our results exclude the possibility that Ral proteins and GTP-dependent exocytosis play critical roles in neurite extension in PC12 cells. The role for Ral in neurite outgrowth may be cell type-specific.

Transfected RalA and RalB are colocalized with secretogranin II inside the tip of neurites of NGF-differentiated PC12 cells We previously showed that Myc-tagged RalA, transfected in wildtype PC12 cells, is localized at the intracellular organelles as well as the plasma membrane and that they are colocalized mostly

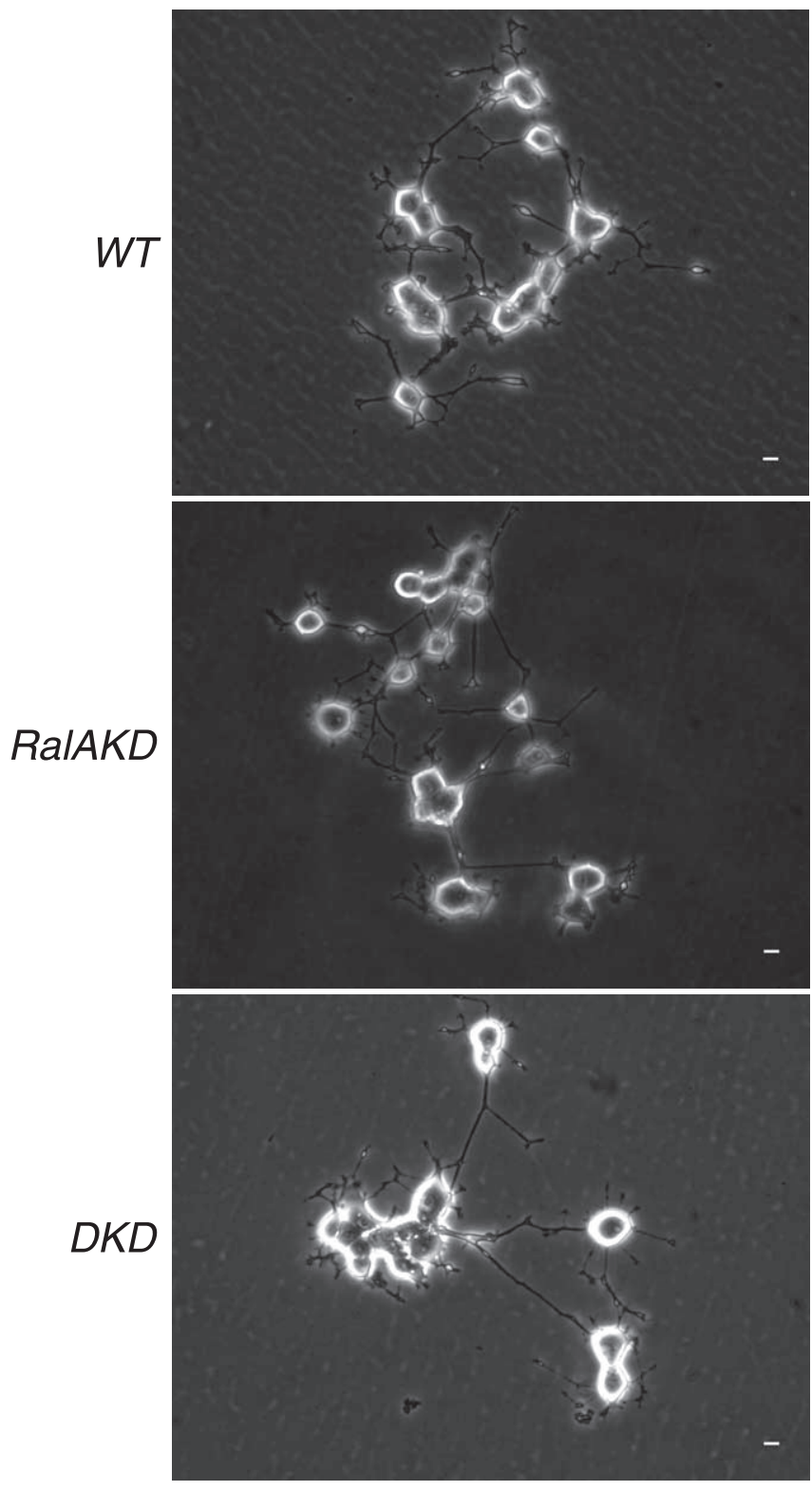

Figure 8. NGF-induced neurite outgrowth is not reduced by the downregulation of RalA/ RalB. The wild-type $\mathrm{PC} 12$ cells (WT), the RalA single knock-down ( $\mathrm{RaI} \mathrm{A}^{\mathrm{KD}} / \mathrm{RaIB}^{\mathrm{C}}$ ) cells (RalAKD), and the RalA/RalB double knock-down (RalA ${ }^{\mathrm{KD} 8} / \mathrm{RaIB}^{\mathrm{KD} 9}$ ) cells (DKD) were treated with NGF (100 ng/ml) for $5 \mathrm{~d}$. Then, the cells were viewed by phase microscopy and photographed. Scale bars, $10 \mu \mathrm{m}$.

with secretogranin II, a marker protein for the dense core vesicles (Wang et al., 2004). We examined the localization of transfected Myc-RalA and Myc-RalB in the double knock-down cells. The Myc-RalA expressed in the double knock-down cells was colocalized mostly with secretogranin II (Fig. 9A-C, top panels). Similarly, transfected Myc-RalB also exhibited colocalization with secretogranin II, although the staining of the plasma membrane by RalB appeared to be more evident (Fig. 9D-F, bottom panels). Thus similar immunostaining patterns of RalA and RalB and their colocalization with secretogranin II suggest their similar functions in the secretory processes.

We also addressed the localization of transfected RalA and RalB in differentiated PC12 cells. The size of undifferentiated PC12 cells is relatively small ( $\sim 10 \mu \mathrm{m}$ in diameter), which makes it difficult for one to identify the exact localization of each or- 
myc
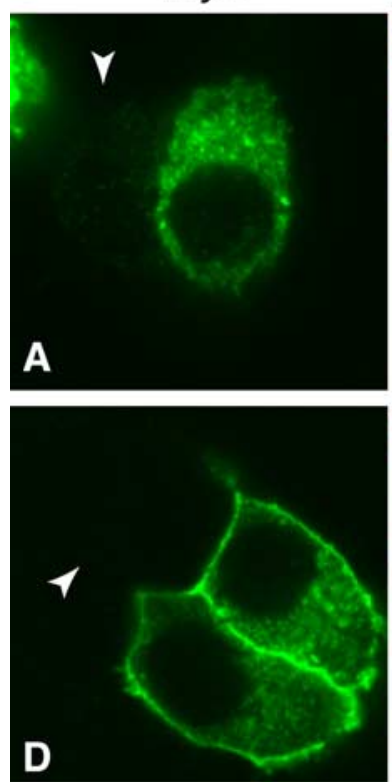

Sgll
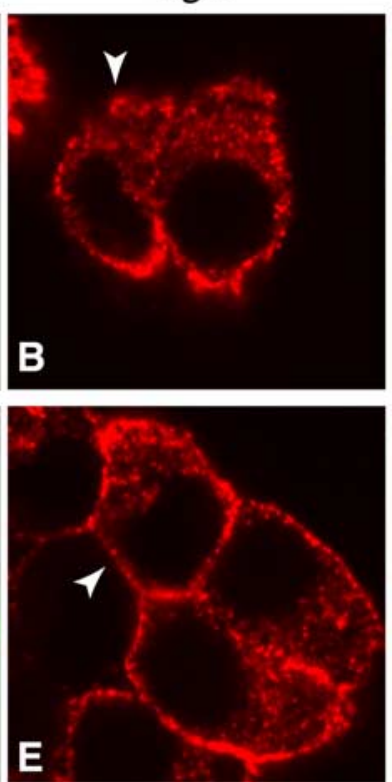

Merge
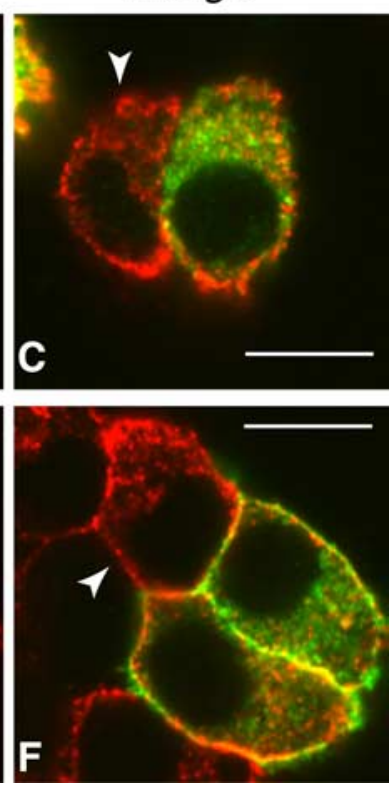

Figure 9. Similar immunolocalization of transfected RalA and RalB in the double knock-down cells. Shown are confocal immunofluorescence images of the RaIA/RaIB double knock-down PC12 cells that were transfected with Myc-RalA $(\boldsymbol{A}-\boldsymbol{C}$, top panels) or Myc-RalB ( $\boldsymbol{D}-\boldsymbol{F}$, bottom panels) expression plasmid. The transfected cells were stained with anti-Myc antibodies (Myc; clone 9E10) followed by Alexa 488-conjugated goat anti-mouse antibodies $(\boldsymbol{A}, \boldsymbol{D})$ and with anti-secretogranin II (Sgll) antibodies followed by Alexa 568-conjugated goat anti-rabbit antibodies $(\boldsymbol{B}, \boldsymbol{E})$. The right panels $(\boldsymbol{C}, \boldsymbol{F})$ show merged images. Arrowheads in $\boldsymbol{A}-\boldsymbol{F}$ indicate untransfected cells. Scale bars, $10 \mu \mathrm{m}$.

ganelle. For example, in undifferentiated PC12 cells it is not easy to distinguish the immunolocalization of dense core vesicles and that of the endoplasmic reticulum. However, under NGFdifferentiated conditions the staining of dense core vesicle marker proteins reveals a strong enrichment at the tip of the neurite (see below), whereas the staining of the endoplasmic reticulum marker proteins (e.g., calnexin) is mostly absent from the tip of the neurite (data not shown). This difference allowed us to distinguish between these two organelles inside the cell; therefore, we began to analyze the localization of Ral proteins in the differentiated PC12 cells by NGF (100 ng/ml). We then investigated the localization of Myc-RalA transfected in the double knock-down (RalA ${ }^{\mathrm{KD} 8} / \mathrm{RalB}^{\mathrm{KD} 9}$ ) cells, using anti-Myc antibody (clone 9E10). Two examples of the immunostaining of transfected Myc-RalA are presented in Figure 10, $A$ and $D$. Untransfected cells (Fig. 10D, arrowhead) served as negative controls that showed the background staining by anti-Myc antibody. We found that the transfected Myc-RalA was localized at the tip of the neurite (indicated by arrows) as well as in the cell body (Fig. $9 A, D)$, where it was colocalized strongly with secretogranin II (Fig. $10 B, C, E, F)$. Higher magnification of the neurite tip revealed granule-like staining patterns of Myc-RalA (Fig. 10G), which happened to colocalize with the secretogranin II staining (Fig. $10 H, I$ ). These results suggest that Myc-RalA is localized primarily at the dense core vesicles in the tip of the neurite and at the cell body. We next examined the localization of Myc-RalB transfected in the double knock-down cells, using Myc antibody. Again, untransfected cells (supplemental Fig. $1 B$, indicated by arrowheads, available at www.jneurosci.org as supplemental material) served as negative controls that showed the background staining by anti-Myc antibody. We found that Myc-RalB showed a similar immunolocalization to Myc-RalA (supplemental Fig. $1 A, D$, available at www.jneurosci.org as supplemental material) and that it was colocalized with secretogranin II (supplemental Fig. $1 B, C, E, F$, available at www.jneurosci.org as supplemental material). Similar immunostaining patterns of Myc-RalA and Myc-RalB and their colocalization with secretogranin II support the similar functions of RalA and RalB in the secretory processes. We also attempted to identify the localization of endogenous RalA by using available antiRalA monoclonal antibody (BD Biosciences), but our analysis of endogenous RalA localization was hampered because of the nonspecific staining by this antibody.

\section{Discussion}

Many secretory cells, including mast cells (Gomperts, 1983; Fernandez et al., 1984), chromaffin cells (Bittner et al., 1986; Ahnert-Hilger et al., 1992; Burgoyne and Hankel, 1994), melanotrophs (Okano et al., 1993), pituitary gonadotrophs (Tse et al., 2000), insulin-secreting $\beta$-cells (Regazzi et al., 1989), and platelets (Padfield et al., 1996; Chen et al., 2000), exhibit GTPdependent exocytosis, but the underlying mechanism has been a mystery for a long time (Pinxteren et al., 2000). In this study we provided pivotal evidence that endogenous RalA and RalB are the key GTPases for GTP-dependent exocytosis. We have demonstrated that downregulation of both RalA and RalB GTPases results in severe reductions of GTP-dependent exocytosis (Fig. 3), whereas downregulation of RalA alone results in limited reduction (Fig. 1). In addition, expression of RalA or RalB by transfection in the double knock-down cells restores GTP-dependent exocytosis (Fig. 4). Furthermore, endogenous RalA, as well as transfected RalA and $\mathrm{RalB}$, is expressed primarily at the granule-like structures at the tip of neurites and colocalized with secretogranin II in undifferentiated (Fig. 9) and NGF-differentiated PC12 cells (Fig. 10) (supplemental Fig. 1, available at www.jneurosci.org as supplemental material). These results strongly suggest that RalA and RalB are the long sought-after GTPases that function as GTP sensors for dense core vesicles in GTP-dependent exocytosis, at least in neuroendocrine PC12 cells.

We also addressed the relationship between $\mathrm{Ca}^{2+}$-dependent exocytosis and GTP-dependent exocytosis (Figs. 5, 6), which until now has been understood poorly. One fact that we and others knew is that these two forms of exocytosis are both SNAREdependent (Banerjee et al., 1996; Glenn and Burgoyne, 1996; Wang et al., 2004). Whereas Martin and coworkers found that cytosolic proteins including phosphatidylcholine transfer protein (Hay and Martin, 1993), phosphatidylinositol phosphate kinases (Hay and Martin, 1993; Aikawa and Martin, 2003; Wang et al., 2005) and CAPS ( $\mathrm{Ca}^{2+}$-dependent activator protein for secretion) (Walent et al., 1992) are critical for $\mathrm{Ca}^{2+}$-dependent exocytosis, they also found that these proteins are dispensable for GTP-dependent exocytosis (Klenchin et al., 1998). These findings suggest that GTP-dependent and $\mathrm{Ca}^{2+}$-dependent exocytosis could be mechanistically different. Our finding now complements theirs because downregulation of both RalA and RalB strongly impairs GTP-dependent exocytosis without affecting 
$\mathrm{Ca}^{2+}$-dependent exocytosis (Figs. 4-6). Thus these two forms of exocytosis use different sensors and effectors before converging onto the SNARE-dependent fusion step. In addition, our present results, together with our previous findings (Wang et al., 2004), provide the first mechanistic model for GTP-dependent exocytosis. We propose that RalA and RalB GTPases function as the major GTP sensors and that their interactions with the exocyst protein complex trigger GTP-dependent exocytosis. In $\mathrm{Ca}^{2+}$-dependent exocytosis the synaptotagmin family members function as the major sensors for $\mathrm{Ca}^{2+}(\mathrm{Gep}-$ pert et al., 1994), and $\mathrm{Ca}^{2+}$-dependent interactions between synaptotagmins and phospholipids (including phosphatidylinositol 4,5-bisphosphates) have been considered to be critical for triggering exocytosis (Sugita et al., 2002; Tucker et al., 2004; Arac et al., 2006).

Our finding appears to contradict in part the results of Moskalenko et al. (2002) and Vitale et al. (2005). Moskalenko et al. (2002) found that overexpression of the wild-type RalB and constitutively active RalB, but not inactive RalB, inhibits high $\mathrm{K}^{+}$-induced $\mathrm{Ca}^{2+}$-dependent secretion of cotransfected human growth hormone, suggesting a negative regulation of $\mathrm{Ca}^{2+}$. dependent exocytosis by RalB. Vitale et al. (2005) found that the transient downregulation of RalA or the overexpression of dominant-negative RalA inhibits $\mathrm{Ca}^{2+}$ dependent human growth hormone secretion, whereas overexpression of constitutively active RalA enhances the secretion, suggesting a positive regulation of $\mathrm{Ca}^{2+}$.

dependent exocytosis by RalA. Vitale et al. (2005) also suggested that the contribution of RalA to $\mathrm{Ca}^{2+}$-dependent exocytosis is via activation of phospholipase D1. Although these two studies suggest that RalA and RalB play opposite functions in $\mathrm{Ca}^{2+}$ dependent exocytosis, their physical similarities in terms of the interactions with the exocyst proteins (Moskalenko et al., 2002; Sugihara et al., 2002; Fukai et al., 2003; Jin et al., 2005) and the cellular localizations (this study) do not appear to support their opposite functions in exocytosis. Our results show that stable RalA/RalB knock-down cells exhibit robust $\mathrm{Ca}^{2+}$-dependent exocytosis (Figs. 5, 6), which excludes their major functions in $\mathrm{Ca}^{2+}$-dependent exocytosis.

Although GTP-dependent exocytosis, in addition to $\mathrm{Ca}^{2+}$ dependent exocytosis, appears to play a major role in the regulation of various secretory pathways, its physiological significance remains to be clarified. For example, it is not clear under which physiological conditions Ral GTPases are activated and stimulate exocytotic secretion. The future goal of our study of Ral GTPases, as well as GTP-dependent exocytosis, will be to identify their physiological functions. It is known that Ral GTPases are activated by several guanine nucleotide dissociation stimulators (GDSs; also called guanine nucleotide exchange factors, GEFs), including RalGDS (Albright et al., 1993), Rgl (RalGDS-like, Kikuchi et al., 1994), Rlf [RalGDS-like factor, also called Rgl2
(Wolthuis et al., 1996)], and RalGEF2 (de Bruyn et al., 2000). Interestingly, RalGDS, Rgl, and Rlf contain a C-terminal Rasbinding domain and interact with the active form of Ras or Raslike GTPases (Kikuchi et al., 1994; Spaargaren and Bischoff, 1994; Wolthuis et al., 1996; Feig, 2003). Therefore, Ral has been considered to function downstream of Ras-signaling pathways. In PC12 cells the activation of Ras by NGF is critical for NGFinduced neurite outgrowth and cell cycle arrest (Hagag et al., 1986; Robbins et al., 1992; Wood et al., 1992). In addition, recent studies have shown that the transient knock-down of RalA and/or RalB inhibits neurite branching in cortical neurons (Lalli and Hall, 2005). Hence we anticipated that the downregulation of RalA and RalB inhibits NGF-induced neurite outgrowth. Surprisingly, however, we did not find this inhibition in RalA/RalB double knock-down cells (Fig. 8). We still could not exclude the possibility that intact NGF-induced neurite outgrowth in the double knock-down cells is mediated via the residual RalA and/or RalB in the knock-down cells. In agreement with our results, Goi et al. (1999) found that the overexpression of the RalGEF domain suppressed NGF-induced neurite outgrowth, suggesting that Ral signaling pathways antagonize Ras signaling pathways in NGFinduced neurite outgrowth. It appears that Ral signaling pathways are regulated not only by the Ras pathways but also by other pathways. Establishing RalA/RalB double knock-down cells, as 
we have done in our research, is an important step in investigating the physiological roles/significance of Ral signaling pathways as well as GTP-dependent exocytosis. Additional analyses of double knock-down cells will shed light on the complex signaling pathways mediated by Ral GTPases.

\section{References}

Ahnert-Hilger G, Wegenhorst U, Stecher B, Spicher K, Rosenthal W, Gratz M (1992) Exocytosis from permeabilized bovine adrenal chromaffin cells is differently modulated by guanosine $5^{\prime}$-[ $\gamma$-thio]triphosphate and guanosine $5^{\prime}$ - $[\beta \gamma$-imido $]$ triphosphate. Evidence for the involvement of various guanine nucleotide-binding proteins. Biochem J 284:321-326.

Aikawa Y, Martin TF (2003) ARF6 regulates a plasma membrane pool of phosphatidylinositol $(4,5)$ bisphosphate required for regulated exocytosis. J Cell Biol 162:647-659.

Albright CF, Giddings BW, Liu J, Vito M, Weinberg RA (1993) Characterization of a guanine nucleotide dissociation stimulator for a ras-related GTPase. EMBO J 12:339-347.

Arac D, Chen X, Khant HA, Ubach J, Ludtke SJ, Kikkawa M, Johnson AE, Chiu W, Südhof TC, Rizo J (2006) Close membrane-membrane proximity induced by $\mathrm{Ca}^{2+}$-dependent multivalent binding of synaptotagmin-1 to phospholipids. Nat Struct Mol Biol 13:209-217.

Banerjee A, Kowalchyk JA, DasGupta BR, Martin TF (1996) SNAP-25 is required for a late postdocking step in $\mathrm{Ca}^{2+}$-dependent exocytosis. J Biol Chem 271:20227-20230

Bittner MA, Holz RW, Neubig RP (1986) Guanine nucleotide effects on catecholamine secretion from digitonin-permeabilized adrenal chromaffin cells. J Biol Chem 261:10182-10188.

Brummelkamp TR, Bernards R, Agami R (2002) A system for stable expression of short interfering RNAs in mammalian cells. Science 296:550-553.

Brymora A, Valova VA, Larsen MR, Roufogalis BD, Robinson PJ (2001) The brain exocyst complex interacts with RalA in a GTP-dependent manner: identification of a novel mammalian $\operatorname{Sec} 3$ gene and a second Sec15 gene. J Biol Chem 276:29792-29797.

Burgoyne RD, Hankel SE (1994) Activation of exocytosis by GTP analogues in adrenal chromaffin cells revealed by patch-clamp capacitance measurement. FEBS Lett 344:139-142.

Chen D, Lemons PP, Schraw T, Whiteheart SW (2000) Molecular mechanisms of platelet exocytosis: role of SNAP-23 and syntaxin 2 and 4 in lysosome release. Blood 96:1782-1788.

Chen YA, Scales SJ, Patel SM, Doung YC, Scheller RH (1999) SNARE complex formation is triggered by $\mathrm{Ca}^{2+}$ and drives membrane fusion. Cell 97:165-174.

de Bruyn KM, de Rooij J, Wolthuis RM, Rehmann H, Wesenbeek J, Cool RH, Wittinghofer AH, Bos JL (2000) RalGEF2, a pleckstrin homology domain containing guanine nucleotide exchange factor for Ral. J Biol Chem 275:29761-29766.

Feig LA (2003) Ral-GTPases: approaching their 15 minutes of fame. Trends Cell Biol 13:419-425.

Fernandez JM, Neher E, Gomperts BD (1984) Capacitance measurements reveal stepwise fusion events in degranulating mast cell. Nature 312:453-455.

Fischer von Mollard G, Mignery GA, Baumert M, Perin MS, Hanson TJ, Burger PM, Jahn R, Südhof TC (1990) Rab3 is a small GTP-binding protein exclusively localized to synaptic vesicles. Proc Natl Acad Sci USA 87:1988-1992.

Fukai S, Matern HT, Jagath JR, Scheller RH, Brunger AT (2003) Structural basis of the interaction between RalA and Sec5, a subunit of the sec6/8 complex. EMBO J 22:3267-3278.

Geppert M, Goda Y, Hammer RE, Li C, Rosahl TW, Stevens CF, Südhof TC (1994) Synaptotagmin I: a major $\mathrm{Ca}^{2+}$ sensor for transmitter release at a central synapse. Cell 79:717-727.

Glenn DE, Burgoyne RD (1996) Botulinum neurotoxin light chains inhibit both $\mathrm{Ca}^{2+}$-induced and GTP analogue-induced catecholamine release from permeabilized adrenal chromaffin cells. FEBS Lett 386:137-140.

Goi T, Rusanescu G, Urano T, Feig LA (1999) Ral-specific guanine nucleotide exchange factor activity opposes other Ras effectors in PC12 cells by inhibiting neurite outgrowth. Mol Cell Biol 19:1731-1741.

Gomperts BD (1983) Involvement of guanine nucleotide-binding protein in the gating of $\mathrm{Ca}^{2+}$ by receptors. Nature 306:64-66.

Greene LA, Tischler AS (1976) Establishment of a noradrenergic clonal line of rat adrenal pheochromocytoma cells which respond to nerve growth factor. Proc Natl Acad Sci USA 73:2424-2428.

Guo W, Roth D, Walch-Solimena C, Novick P (1999) The exocyst is an effector for Sec4p, targeting secretory vesicles to sites of exocytosis. EMBO J 18:1071-1080.

Hagag N, Halegoua S, Viola M (1986) Inhibition of growth factor-induced differentiation of PC12 cells by microinjection of antibody to ras p21. Nature 319:680-682.

Hay JC, Martin TF (1993) Phosphatidylinositol transfer protein required for ATP-dependent priming of $\mathrm{Ca}^{2+}$-activated secretion. Nature 366:572-575.

Hay JC, Fisette PL, Jenkins GH, Fukami K, Takenawa T, Anderson RA, Martin TF (1995) ATP-dependent inositide phosphorylation required for $\mathrm{Ca}^{2+}$-activated secretion. Nature 374:173-177.

Hsu SC, Ting AE, Hazuka CD, Davanger S, Kenny JW, Kee Y, Scheller RH (1996) The mammalian brain rSec6/8 complex. Neuron 17:1209-1219.

Irwin N, Chao S, Goritchenko L, Horiuchi A, Greengard P, Nairn AC, Benowitz LI (2002) Nerve growth factor controls GAP-43 mRNA stability via the phosphoprotein ARPP-19. Proc Natl Acad Sci USA 99:12427-12431.

Jin R, Junutula JR, Matern HT, Ervin KE, Scheller RH, Brunger AT (2005) Exo84 and Sec5 are competitive regulatory Sec6/8 effectors to the RalA GTPase. EMBO J 24:2064-2074.

Kee Y, Yoo JS, Hazuka CD, Peterson KE, Hsu SC, Scheller RH (1997) Subunit structure of the mammalian exocyst complex. Proc Natl Acad Sci USA 94:14438-14443.

Kikuchi A, Demo SD, Ye ZH, Chen YW, Williams LT (1994) RalGDS family members interact with the effector loop of ras p21. Mol Cell Biol 14:7483-7491.

Klenchin VA, Kowalchyk JA, Martin TF (1998) Large dense-core vesicle exocytosis in PC12 cells. Methods 16:204-208.

Lalli G, Hall A (2005) Ral GTPases regulate neurite branching through GAP-43 and the exocyst complex. J Cell Biol 171:857-869.

Li G, Lee D, Wang L, Khvotchev M, Chiew SK, Arunachalam L, Collins T, Feng ZP, Sugita S (2005) N-terminal insertion and C-terminal ankyrinlike repeats of $\alpha$-latrotoxin are critical for $\mathrm{Ca}^{2+}$-dependent exocytosis. J Neurosci 25:10188-10197.

Moskalenko S, Henry DO, Rosse C, Mirey G, Camonis JH, White MA (2002) The exocyst is a Ral effector complex. Nat Cell Biol 4:66-72.

Moskalenko S, Tong C, Rosse C, Mirey G, Formstecher E, Daviet L, Camonis J, White MA (2003) Ral GTPases regulate exocyst assembly through dual subunit interactions. J Biol Chem 278:51743-51748.

Munemitsu S, Innis MA, Clark R, McCormick F, Ullrich A, Polakis P (1990) Molecular cloning and expression of a G25K cDNA, the human homolog of the yeast cell cycle gene CDC42. Mol Cell Biol 10:5977-5982.

Nagai T, Ibata K, Park ES, Kubota M, Mikoshiba K, Miyawaki A (2002) A variant of yellow fluorescent protein with fast and efficient maturation for cell-biological applications. Nat Biotechnol 20:87-90.

Ning K, Pei L, Liao M, Liu B, Zhang Y, Jiang W, Mielke JG, Li L, Chen Y, El-Hayek YH, Fehlings MG, Zhang X, Liu F, Eubanks J, Wan Q (2004) Dual neuroprotective signaling mediated by downregulating two distinct phosphatase activities of PTEN. J Neurosci 24:4052-4060.

Okano K, Monck JR, Fernandez JM (1993) GTP $\gamma$ S stimulates exocytosis in patch-clamped rat melanotrophs. Neuron 11:165-172.

Padfield PJ, Panesar N, Henderson P, Baldassare JJ (1996) Differential effects of G-protein activators on 5-hydroxytryptamine and plateletderived growth factor release from streptolysin O-permeabilized human platelets. Biochem J 314:123-128.

Pinxteren JA, O'Sullivan AJ, Larbi KY, Tatham PE, Gomperts BD (2000) Thirty years of stimulus-secretion coupling: from $\mathrm{Ca}^{2+}$ to GTP in the regulation of exocytosis. Biochimie 82:385-393.

Polakis PG, Weber RF, Nevins B, Didsbury JR, Evans T, Synderman R (1989) Identification of the ral and racl gene products, low molecular mass GTP-binding proteins from human platelets. J Biol Chem 264:16383-16389.

Regazzi R, Li G, Ullrich S, Jaggi C, Wollheim CB (1989) Different requirements for protein kinase $\mathrm{C}$ activation and $\mathrm{Ca}^{2+}$-independent insulin secretion in response to guanine nucleotides. Endogenously generated diacylglycerol requires elevated $\mathrm{Ca}^{2+}$ for kinase $\mathrm{C}$ insertion into membranes. J Biol Chem 264:9939-9944.

Robbins DJ, Cheng M, Zhen E, Vanderbilt CA, Feig LA, Cobb MH (1992) 
Evidence for a Ras-dependent extracellular signal-regulated protein kinase (ERK) cascade. Proc Natl Acad Sci USA 89:6924-6928.

Rosse C, Hatzoglou A, Parrini MC, White MA, Chavrier P, Camonis J (2006) RalB mobilizes the exocyst to drive cell migration. Mol Cell Biol 26:727-734.

Schweitzer ES (1993) Regulated and constitutive secretion of distinct molecular forms of acetylcholinesterase from PC12 cells. J Cell Sci 106:731-740.

Sollner T, Whiteheart SW, Brunner M, Erdjument-Bromage H, Geromanos S, Tempst P, Rothman JE (1993) SNAP receptors implicated in vesicle targeting and fusion. Nature 362:318-324.

Spaargaren M, Bischoff JR (1994) Identification of the guanine nucleotide dissociation stimulator for $\mathrm{Ral}$ as a putative effector molecule of R-ras, H-ras, K-ras, and Rap. Proc Natl Acad Sci USA 91:12609-12613.

Sugihara K, Asano S, Tanaka K, Iwamatsu A, Okawa K, Ohta Y (2002) The exocyst complex binds the small GTPase RalA to mediate filopodia formation. Nat Cell Biol 4:73-78.

Sugita S (2004) Human growth hormone co-transfection assay to study molecular mechanisms of neurosecretion in PC12 cells. Methods 33:267-272.

Sugita S, Janz R, Südhof TC (1999) Synaptogyrins regulate $\mathrm{Ca}^{2+}$-dependent exocytosis in PC12 cells. J Biol Chem 274:18893-18901.

Sugita S, Han W, Butz S, Liu X, Fernandez-Chacon R, Lao Y, Südhof TC (2001) Synaptotagmin VII as a plasma membrane $\mathrm{Ca}^{2+}$ sensor in exocytosis. Neuron 30:459-473.

Sugita S, Shin OH, Han W, Lao Y, Südhof TC (2002) Synaptotagmins form a hierarchy of exocytotic $\mathrm{Ca}^{2+}$ sensors with distinct $\mathrm{Ca}^{2+}$ affinities. EMBO J 21:270-280.

TerBush DR, Novick P (1995) Sec6, Sec8, and Sec15 are components of a multisubunit complex which localizes to small bud tips in Saccharomyces cerevisiae. J Cell Biol 130:299-312.
TerBush DR, Maurice T, Roth D, Novick P (1996) The exocyst is a multiprotein complex required for exocytosis in Saccharomyces cerevisiae. EMBO J 15:6483-6494.

Tse FW, Tse A (2000) Stimulation of $\mathrm{Ca}^{2+}$-independent exocytosis in rat pituitary gonadotrophs by G-protein. J Physiol (Lond) 526:99-108.

Tsuboi T, Ravier MA, Xie H, Ewart MA, Gould GW, Baldwin SA, Rutter GA (2005) Mammalian exocyst complex is required for the docking step of insulin vesicle exocytosis. J Biol Chem 280:25565-25570.

Tucker WC, Weber T, Chapman ER (2004) Reconstitution of $\mathrm{Ca}^{2+}$ regulated membrane fusion by synaptotagmin and SNAREs. Science 304:435-438.

Vitale N, Mawet J, Camonis J, Regazzi R, Bader MF, Chasserot-Golaz S (2005) The small GTPase RalA controls exocytosis of large dense core secretory granules by interacting with ARF6-dependent phospholipase D1. J Biol Chem 280:29921-29928.

Walent JH, Porter BW, Martin TF (1992) A novel 145 kd brain cytosolic protein reconstitutes $\mathrm{Ca}^{2+}$-regulated secretion in permeable neuroendocrine cells. Cell 70:765-775.

Wang L, Li G, Sugita S (2004) RalA-exocyst interaction mediates GTPdependent exocytosis. J Biol Chem 279:19875-19881.

Wang L, Li G, Sugita S (2005) A central kinase domain of type I phosphatidylinositol phosphate kinases is sufficient to prime exocytosis: isoform specificity and its underlying mechanism. J Biol Chem 280:16522-165227.

Wolthuis RM, Bauer B, van't Veer LJ, de Vries-Smits AM, Cool RH, Spaargaren M, Wittinghofer A, Burgering BM, Bos JL (1996) RalGDS-like factor (Rlf) is a novel Ras and Rap 1A-associating protein. Oncogene 13:353-362.

Wood KW, Sarnecki C, Roberts TM, Blenis J (1992) ras mediates nerve growth factor receptor modulation of three signal-transducing protein kinases: MAP kinase, Raf-1, and RSK. Cell 68:1041-1050. 